\title{
Hydrological response of a small catchment burned by experimental fire
}

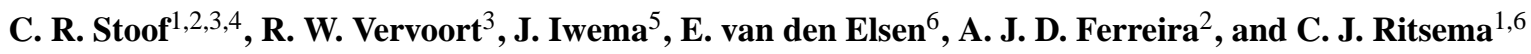 \\ ${ }^{1}$ Land Degradation and Development Group, Wageningen University, Wageningen, The Netherlands \\ ${ }^{2}$ CERNAS, Escola Superior Agrária de Coimbra. Bencanta, 3040-316 Coimbra, Portugal \\ ${ }^{3}$ Faculty of Agriculture, Food \& Natural Resources, The University of Sydney, Sydney, Australia \\ ${ }^{4}$ Department of Biological and Environmental Engineering, Cornell University, Ithaca, NY, USA \\ ${ }^{5}$ Hydrology and Quantitative Water Management Group, Wageningen University, Wageningen, The Netherlands \\ ${ }^{6}$ Alterra Green World Research, Wageningen UR, Wageningen, The Netherlands
}

Correspondence to: C. R. Stoof (cathelijne.stoof@ cornell.edu)

Received: 17 February 2011 - Published in Hydrol. Earth Syst. Sci. Discuss.: 26 April 2011

Revised: 19 January 2012 - Accepted: 20 January 2012 - Published: 2 February 2012

\begin{abstract}
Fire can considerably change hydrological processes, increasing the risk of extreme flooding and erosion events. Although hydrological processes are largely affected by scale, catchment-scale studies on the hydrological impact of fire in Europe are scarce, and nested approaches are rarely used. We performed a catchment-scale experimental fire to improve insight into the drivers of fire impact on hydrology. In north-central Portugal, rainfall, canopy interception, streamflow and soil moisture were monitored in small shrub-covered paired catchments pre- and post-fire. The shrub cover was medium dense to dense ( 44 to $84 \%$ ) and pre-fire canopy interception was on average $48.7 \%$ of total rainfall. Fire increased streamflow volumes 1.6 times more than predicted, resulting in increased runoff coefficients and changed rainfall-streamflow relationships - although the increase in streamflow per unit rainfall was only significant at the subcatchment-scale. Fire also fastened the response of topsoil moisture to rainfall from 2.7 to $2.1 \mathrm{~h}(p=0.058)$, and caused more rapid drying of topsoils after rain events. Since soil physical changes due to fire were not apparent, we suggest that changes resulting from vegetation removal played an important role in increasing streamflow after fire. Results stress that fire impact on hydrology is largely affected by scale, highlight the hydrological impact of fire on small scales, and emphasize the risk of overestimating fire impact when upscaling plot-scale studies to the catchmentscale. Finally, they increase understanding of the processes contributing to post-fire flooding and erosion events.
\end{abstract}

\section{Introduction}

Wildfires can increase a landscape's vulnerability to major flooding and erosion events (Shakesby and Doerr, 2006). By removing vegetation cover, changing soil properties and inducing soil water repellency, fire can increase runoff which can lead to floods and erosion (Cerdà and Robichaud, 2009). However, the impact of fire is largely affected by scale. Despite this scaling challenge, which is universal across all hydrological problems (Blöschl and Sivapalan, 1995), catchment-scale studies on the hydrological impact of fire are generally only performed in Australia and the USA. Even though controlled fire experiments can give valuable insight into the drivers of fire-induced hydrological changes and effects of scale, to date catchment-scale controlled fire experiments have not been performed and particularly nested approaches are rarely used.

Vegetation cover is an important factor in determining runoff and erosion risk. Its removal by fire increases raindrop impact on the bare soil, and reduces storage of rainfall in the canopy, thus increasing the amount of effective rainfall. Moreover, the removal of vegetation can have major impact on soil moisture status. Exposure of the soil surface to atmospheric forcings can considerably increase soil evaporation, which is why vegetation cover is often identified as an important factor protecting the soil from heating up and drying out (Hulbert, 1969; Stoof et al., 2011; Sumrall et al., 1991; White and Currie, 1983). The net change in soil moisture 
is highly dependent on depth: the increase in soil evaporation can result in drier topsoil, in contrast to subsoils that can actually get wetter because of the marked reduction in plant transpiration (Silva et al., 2006). While this reduced depletion of soil water creates favorable conditions for subsurface runoff, changes in topsoil moisture can considerably impact surface runoff in areas prone to soil water repellency because the degree of soil water repellency is strongly related to soil moisture content (Dekker et al., 2001; Leighton-Boyce et al., 2005; Stoof et al., 2011; Thwaites et al., 2006).

High soil temperatures during fire can additionally affect post-fire hydrological processes since the heat of fire can cause considerable damage to the soil system (Cerdà and Robichaud, 2009; Stoof et al., 2010), Of particular importance in post-fire hydrology is reduced infiltration resulting from, for instance: (1) possible pore-clogging by infiltrated ash (Woods and Balfour, 2008; Onda et al., 2008; Stoof et al., 2010), (2) development of soil water repellency during and after fire (DeBano, 2000b, Stoof et al., 2011), and (3) occurrence of surface sealing due to the increased exposure to raindrop impact (Larsen et al., 2009; Llovet et al., 2008). In addition, pronounced soil heating can reduce soil water retention capacity (Stoof et al., 2010) and also contribute to a changed post-fire rainfall runoff response.

Given the abovementioned changes in effective rainfall, evaporation, transpiration, water infiltration and retention, fire tends to increase the runoff coefficient, or the fraction of rainfall converted to runoff (Onda et al., 2008; Rosso et al., 2007; Rulli et al., 2006; Scott and Van Wyk, 1990). As a result, a number of studies have reported initial increases in overland flow (Beeson et al., 2001; Johansen et al., 2001; Prosser and Williams, 1998) and peakflow volumes after fire (Brown, 1972; Scott, 1993; Seibert et al., 2010), explaining the increased vulnerability of burned areas to flooding events. Observed increases in annual and dry season streamflow (Brown, 1972; Hibbert, 1967; McMichael and Hope, 2007) can furthermore contribute to flooding as a cumulative effect. Since the hydrological impact of fire is related to soil and vegetation changes, the longevity of the hydrological impact is related to the recovery time of soil and vegetation, which varies between ecosystems and can be as rapid as a few years but also as long as many decades (Shakesby and Doerr, 2006).

As mentioned, hydrological processes are highly affected by scale, both in burned and unburned systems (Blöschl and Sivapalan, 1995; Shakesby and Doerr, 2006; Van der Velde et al., 2011). Due to the effects of mixing and filtering (Skøien et al., 2003) and reduced hydrological connectivity at larger scales (Bracken and Croke, 2007; Cammeraat, 2002), changes observed at the plot-scale tend to overestimate changes occurring at the hillslope- or catchmentscale (e.g. Doerr et al., 2003; Prosser and Williams, 1998). For example, increased patchiness and storage at the catchment scale (Ferreira et al., 1997) can facilitate infiltration of runoff downslope, which reduces overland- and streamflow volumes. Because of the pronounced effect of scale on postfire hydrology, fire effects on flooding risk are best assessed at the catchment scale. Yet, as previously noted, catchment scale hydrological studies assessing fire impact are scarce (Shakesby et al., 2006; Shakesby, 2011).

Although controlled fire experiments are a useful tool for assessment of fire impact in the field, such experiments have to date been restricted mostly to plot and hillslope scales. As a result, (small) catchment-scale fire studies are limited to impact assessment of accidental wildfires in previously or actively monitored watersheds (e.g. Brown, 1972; Meixner and Wohlgemuth, 2003; Scott, 1993), or post-fire assessment of the hydrology of burned catchments (Mayor et al., 2007; Moody and Martin, 2001). In both cases, knowledge of the degree of soil heating during the fire and subsequent impact on soil properties is unknown, thus hindering assessment of all factors contributing to hydrological change. Moreover, despite the high fire occurrence in the European Mediterranean (Moreira et al., 2001; Pausas, 2004), catchment-scale wildfire studies have mostly been conducted in the USA (Gottfried et al., 2003; Meixner and Wohlgemuth, 2003; Nasseri, 1989; Seibert et al., 2010), South Africa (Scott and Van Wyk, 1990; Scott, 1993, 1997) and Australia (Brown, 1972; Langford, 1976; Prosser and Williams, 1998), and at just two locations in the European Mediterranean (Lavabre et al., 1993; Mayor et al., 2007). Better understanding of the hydrological impact of fire at the catchment-scale can improve understanding and therefore possibly prediction of the risk of flooding in burned areas.

The purpose of the present study was to evaluate the impact of fire on hydrological processes and the causes of any changes at the small catchment scale. While investigation of streamflow response to fire can be studied with a solely hydrologic approach that compares streamflow changes in multiple catchments (see for instance Scott, 1993 and Kuczera, 1987), improved understanding of the underlying processes requires a more interdisciplinary approach, joining the soil, water and fire sciences. In a region of Portugal seriously affected by fires and post-fire land degradation, we therefore performed a catchment-scale experimental fire in a small catchment in which soils, fire and hydrology were intensively monitored (Stoof, 2011), to study the processes underlying fire-related increases in flooding and erosion risk. This paper focuses on the effects of the fire on (soil) hydrology and discusses the effects of scale and the value of experimental fire research at the catchment scale. Because the greatest effects of fire on hydrology and erosion generally occur shortly after fire (Ferreira et al., 2009), data analysis and discussion is limited to the short-term $(\leq 1 \mathrm{yr})$ effects.

Our main hypothesis follows the reviewed literature and is that fire alters catchment hydrology as a result of reduced canopy interception and an increased occurrence of soil water repellency. Because post-fire streamflow volumes are larger and streamflow response to rainfall events is more rapid, flooding risk is increased. To test this hypothesis 
and to improve understanding of fire-induced hydrological changes, the effects of fire on streamflow and soil moisture were studied using paired catchments, and the importance of rainfall, canopy interception and soil moisture in streamflow generation was assessed. Soil water repellency dynamics were extensively studied throughout the course of the study, and discussed in a separate paper by Stoof et al. (2011).

\section{Methods}

\subsection{Research catchments}

The study area is located on the eastern slopes of the Serra da Lousã in north-central Portugal (Fig. 1). Precipitation occurs predominantly in winter, with the summer being a pronounced dry period with high wildfire risk. Both research catchments, Valtorto (burned, $9.7 \mathrm{ha}$ ) and the nearby Espinho (control, 4.9 ha) are characterized by an ephemeral stream and are similar in size, exposure, geology and vegetation type (Table 1). Moreover, they lack the man-made terraces often found in (abandoned) valleys in this region, which increase soil water storage potential and thus affect streamflow response. Although the Valtorto catchment is nearly twice the size of the control Espinho catchment, prefire hydrological data shows that the hydrological processes are similar (Sect. 3).

Soils and vegetation are typical for the region. Soils are formed on schist or quartzite bedrock. They are generally shallow gravelly loamy sands (USDA, 1993), rich in organic matter, with considerable rock fragment content and cover (Table 1). The vegetation consists of dense heathland dominated by Erica sp, Ulex sp., Pterospartum tridentatum and Genista triacanthos, regenerated after wildfire burned both catchments in the summer of 1990 and a prescribed fire burned the Valtorto catchment in April 1996. Because of the longer time since the last fire, the vegetation in the Espinho catchment was slightly taller than that in the Valtorto catchment (Table 1). Moreover, because of this 1996 prescribed fire, an existing structure of fire breaks confined the burned area in the Valtorto catchment, which closely matched the shape and size of the topographical watershed defined using ArcGIS (Fig. 1c).

\subsection{Experimental fire}

The Valtorto catchment was burned by a high-intensity experimental fire in winter 2009. The aim was to simulate a wildfire to the greatest extent possible within safety constraints, in order to get a soil hydrological response similar to natural conditions. Details about how the fire was conducted, soil temperature measurements and soil impact assessment can be found in Stoof (2011). In short, the area was burned ten days after the last rainfall on the morning of 20 February 2009. Ring ignition was used to maximize convection and to reach the maximum potential fire intensity un- der the prevailing weather conditions. No post-frontal flaming combustion was observed, which indicated that flame residence time was low. The fire varied spatially in intensity: it was similar in nature to a prescribed fire on the mid- to upper slopes of the catchment but reached a much higher intensity on the valley bottom. While flame temperatures reached $\sim 700^{\circ} \mathrm{C}$ and fire intensity in some places exceeded $15000 \mathrm{~kW} \mathrm{~m}^{-1}$, shrubs were not completely consumed throughout the catchment (Fig. 1c) and soil temperatures remained relatively low: although maximum soil surface temperature was locally as high as $800^{\circ} \mathrm{C}$, soils in the majority of the catchment remained below $100^{\circ} \mathrm{C}$. As a result, soil hydrologic properties such as saturated hydraulic conductivity and soil porosity did not change significantly. However, overland flow resistance and soil surface roughness decreased significantly because of the fire and the post-fire exposure of the soil (Stoof, 2011).

\subsection{Hydrological monitoring}

A paired-catchment design was adopted in order to separate hydrological effects of the experimental fire from natural hydrological variability. Pre- and post-fire time series of rainfall and streamflow were collected in the burned catchment (Valtorto) and in the unburned control catchment (Espinho). Details of the methodology are given in the following paragraphs and summarized in Table 2. Effects of scale on post-fire hydrological processes were assessed using a nested approach. For this purpose, streamflow in the Valtorto catchment was not only monitored at the outlet of the main catchment, but also at the outlet of the 0.13 ha unbounded subcatchment halfway up the southeast slope (Fig. 1c). Finally, topsoil moisture content and canopy interception were monitored in the Valtorto catchment only.

Hydrological monitoring started in August 2007 but due to frequent data logger failure, reliable streamflow and soil moisture data was only collected from May 2008 onwards (10 months before the fire). Replicate rain gauges and water level recorders were installed to ensure continuation of data collection in case of logger failure. In addition, all sensors and data loggers were removed from the catchment the day before the fire to prevent fire damage to the monitoring equipment. All equipment was consequently reinstalled the day after the fire.

\subsubsection{Rainfall and potential evapotranspiration}

Rainfall was recorded at $0.2 \mathrm{~mm}$ intervals using tipping bucket rain gauges (Table 2) mounted above the shrub canopy on $1.5 \mathrm{~m}$-high metal stakes. Two rain gauges were installed in Valtorto, and one in Espinho. Because both rain gauges in Valtorto were highly correlated $(r=0.996$, RSE $0.67 \mathrm{~mm}$ ), the catchment rainfall was calculated as the hourly or daily average of the two gauges. Since instrument failure never occurred for both rain gauges at the same time, there 
a) Portugal

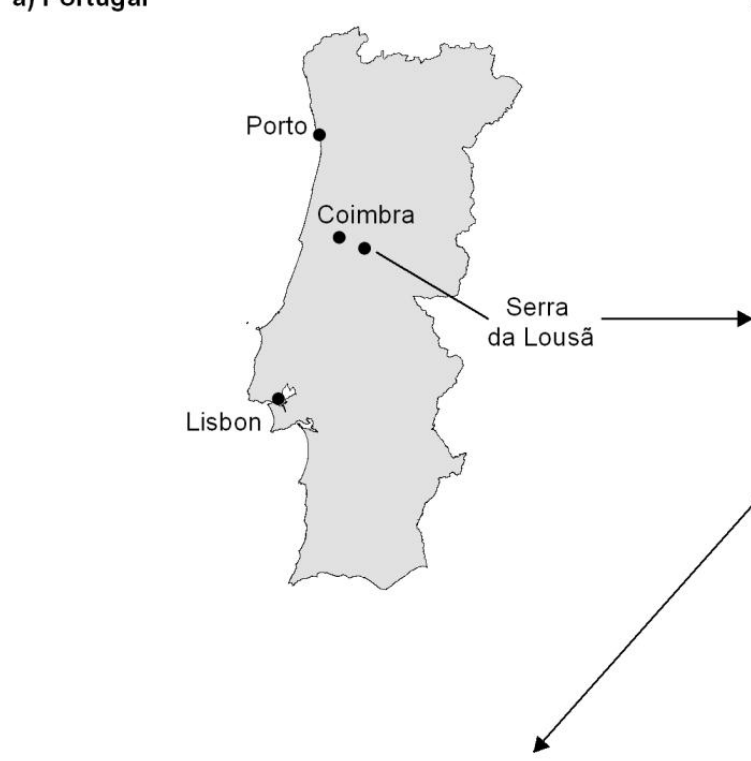

c) Valtorto catchment

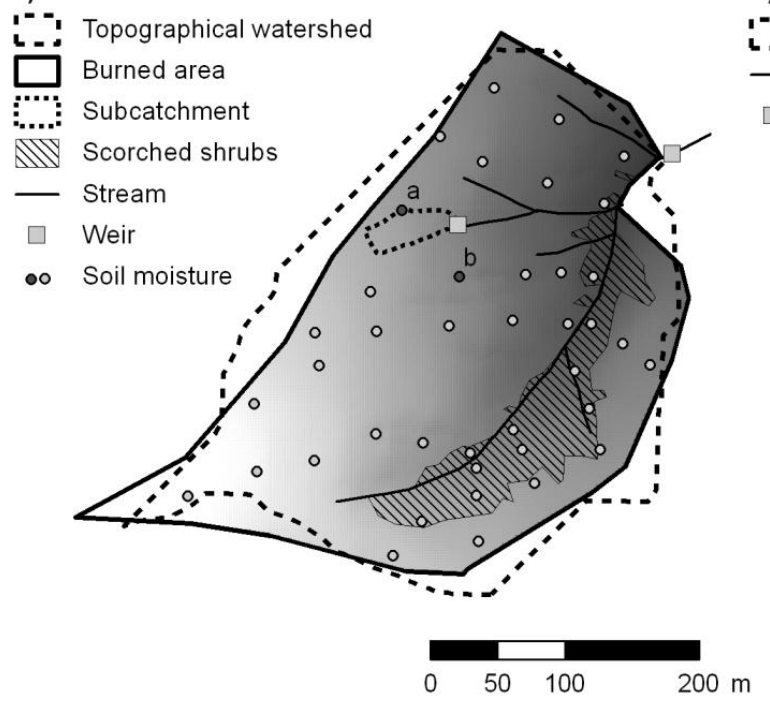

b) Ribeira do Loreiro catchment

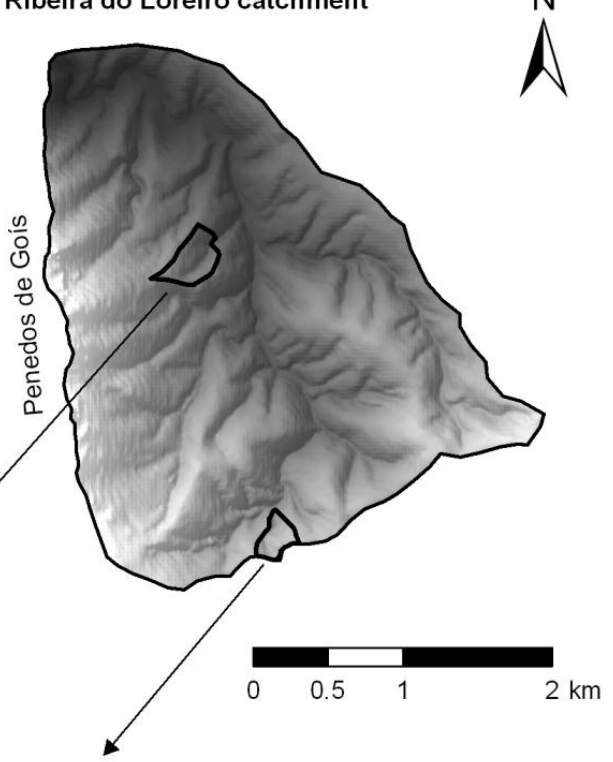

d) Espinho catchment (control)

[-.: Topographical watershed

- Stream

Weir
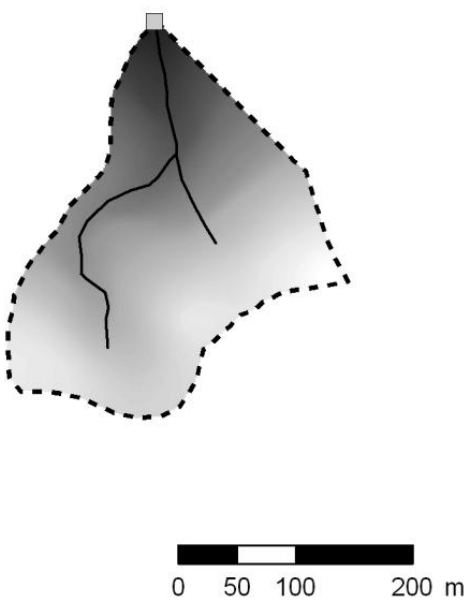

Fig. 1. Location of the Valtorto and Espinho catchments, showing the sampling design. Letters "a" and "b" in graph (c) indicate the soil moisture locations nearest to the subcatchment (see Fig. 10). Grey shading in graphs (b), (c) and (d) represents elevation, enhanced using hillslope shading in ArcGIS.

were no periods of missing data in Valtorto. Missing data in Espinho were filled using the Valtorto bottom gauge, which was slightly better correlated to the Espinho data $(r=0.975$, RSE $2.1 \mathrm{~mm}$ ) than the center gauge.

Potential evapotranspiration data was not measured in the catchment but is measured by the Portuguese Meteorological Institute in the city of Coimbra, $50 \mathrm{~km} \mathrm{NW}$ of the research catchments. Data was acquired from ten-day meteorological bulletins published online at www.meteo.pt.

\subsubsection{Canopy throughfall and interception}

Canopy interception was estimated from cumulative throughfall measurements during the pre-fire winter period, not taking stemflow into account. We cut the tops off of 5-1 water jugs (Table 2), and placed five replicate jugs beneath shrubs at three locations in the catchment, characterized by medium dense ( $44 \pm 27 \%$ cover, $\sim 0.4 \mathrm{~m}$ high), dense $(67 \pm 24 \%$ cover, 0.5 to $0.6 \mathrm{~m}$ high) and tall vegetation ( $84 \pm 21 \%$ cover, 1.5 to $2.0 \mathrm{~m}$ high). Care was taken to make sure that the jugs were level. Cumulative rainfall was measured in a natural clearing close to each location using 
Table 1. Site and soil characteristics of the Valtorto and Espinho catchments, as mapped before the fire. Values are means over the number of observations $(n) \pm$ one standard deviation, and "n.d" stands for "not determined".

\begin{tabular}{|c|c|c|c|c|}
\hline Parameter & \multicolumn{4}{|c|}{ Value } \\
\hline Annual precipitation (mm) & \multicolumn{4}{|c|}{1050} \\
\hline Monthly temperature $\left({ }^{\circ} \mathrm{C}\right)$ & \multicolumn{4}{|c|}{7.8 (Dec); 20 (Aug) } \\
\hline & Valtorto & $n$ & Espinho & $n$ \\
\hline Treatment & Burned & & Control & \\
\hline \multirow[t]{2}{*}{ Location } & $40^{\circ} 06^{\prime} 21^{\prime \prime} \mathrm{N}$ & & $40^{\circ} 05^{\prime} 21^{\prime \prime} \mathrm{N}$ & \\
\hline & $8^{\circ} 07^{\prime} 03^{\prime \prime} \mathrm{W}$ & & $8^{\circ} 06^{\prime} 41^{\prime \prime} \mathrm{W}$ & \\
\hline Size (ha) ${ }^{\mathrm{a}}$ & $9.7^{\mathrm{b}} ; 0.13^{\mathrm{c}}$ & & 4.9 & \\
\hline Percentage burned $(\%)$ & $88^{\mathrm{b}} ; 100^{\mathrm{c}}$ & & 0 & \\
\hline Elevation (m a.s.l.) & $600-750$ & & $695-800$ & \\
\hline DEM slope $(\%)$ & $38 \pm 16$ & & $36 \pm 18$ & \\
\hline Soil depth $(\mathrm{m})$ & $0.16 \pm 0.13$ & 322 & $0.18 \pm 0.13$ & 46 \\
\hline Soil bulk density $\left(\mathrm{g} \mathrm{cm}^{-3}\right)^{\mathrm{d}}$ & $0.82 \pm 0.13$ & 265 & $0.81 \pm 0.16$ & 46 \\
\hline Soil organic matter content (weight $\%)^{\mathrm{d}}$ & $21.0 \pm 5.2$ & 226 & $23.0 \pm 8.9$ & 46 \\
\hline Soil porosity $(\%)^{\mathrm{e}}$ & $60.2 \pm 4.4$ & 42 & n.d. & \\
\hline Saturated hydraulic conductivity $\left(\mathrm{m} \mathrm{d}^{-1}\right) \mathrm{e}$ & $1.4 \pm 0.7$ & 42 & n.d. & \\
\hline Rock fragment content $\left(\mathrm{cm}^{3} \mathrm{~cm}^{-3}\right)^{\mathrm{e}, \mathrm{f}}$ & $0.16 \pm 0.06$ & 247 & $0.18 \pm 0.06$ & 46 \\
\hline Surface rock cover $(\%)$ & $56.0 \pm 26.4$ & 252 & $54.3 \pm 30.1$ & 46 \\
\hline (Pre-fire) vegetation height $(\mathrm{m})$ & $0.50 \pm 0.26$ & 269 & $0.79 \pm 0.41$ & 46 \\
\hline (Pre-fire) vegetation cover $(\%)$ & $80.9 \pm 18.0$ & 246 & $75.3 \pm 18.2$ & 46 \\
\hline
\end{tabular}

a The size of the topographical watershed was defined in ArcGIS, using a digital elevation model of the area and additional expert knowledge. The 10-m DEM was too coarse to determine the size of the Valtorto subcatchment, which was instead determined in the field using a GPS. ${ }^{\mathrm{b}}$ Valtorto main catchment. ${ }^{\mathrm{c}}$ Valtorto subcatchment. ${ }^{\mathrm{d}} 0-2.5 \mathrm{~cm}$ depth. $^{\mathrm{e}} 0-4$ $\mathrm{cm}$ depth. ${ }^{\mathrm{f}}$ Rock fragments are defined as particles $>2 \mathrm{~mm}$, volumetric values given correspond to a gravimetric rock fragment content of $0.407 \pm 0.108$ and $0.458 \pm 0.108 \mathrm{~g} \mathrm{~g}-1$ for Valtorto and Espinho, respectively.

Table 2. Monitoring equipment used in the Valtorto (burned) and Espinho (control) catchments. Since there was no power source available in either catchment, all loggers were stand-alone, had individual batteries, and were downloaded manually.

\begin{tabular}{|c|c|c|c|c|c|}
\hline \multirow[b]{2}{*}{ Parameter } & \multicolumn{2}{|c|}{ \# Monitoring sites } & \multirow[b]{2}{*}{ Equipment/Probe and data logger } & \multirow[b]{2}{*}{$\begin{array}{l}\text { Monitoring } \\
\text { interval }\end{array}$} & \multirow[b]{2}{*}{ Time period } \\
\hline & $\begin{array}{l}\text { Valtorto } \\
\text { (burned) }\end{array}$ & $\begin{array}{l}\text { Espinho } \\
\text { (control) }\end{array}$ & & & \\
\hline Rainfall & 2 & 1 & $\begin{array}{l}\text { Tipping bucket rain collector (Davis Instruments, } \\
\text { CA, USA) with Odyssey data recorder (Dataflow } \\
\text { Systems, New Zealand) }\end{array}$ & $0.2 \mathrm{~mm}$ & Aug 2007-Feb 2010 \\
\hline $\begin{array}{l}\text { Canopy } \\
\text { throughfall/ } \\
\text { interception }\end{array}$ & 3 & $\mathrm{n} / \mathrm{a}$ & $\begin{array}{l}\text { 5-1 water jugs }\left(25 \mathrm{~cm} \text { high, } 196.5 \mathrm{~cm}^{2}\right) \text { using five } \\
\text { replicates and one cumulative rainfall measure- } \\
\text { ment per site, manual observation }{ }^{\mathrm{a}}\end{array}$ & (bi)weekly & Nov 2008-Feb 2009 \\
\hline \multirow[t]{2}{*}{ Streamflow } & $2^{b}$ & 1 & $\begin{array}{l}\text { Odyssey capacitance water level probe (Dataflow } \\
\text { Systems, New Zealand) }\end{array}$ & $5 \mathrm{~min}$ & May 2008-Feb 2010 \\
\hline & & & $\begin{array}{l}\text { MiniDiver along with BaroDiver for air pressure } \\
\text { correction }^{\mathrm{c}} \text { (Schlumberger Water Services, UK) }\end{array}$ & $5 \mathrm{~min}$ & Jul 2008-Feb 2010 \\
\hline Soil moisture & 40 & $\mathrm{n} / \mathrm{a}$ & $\begin{array}{l}\text { EC-5 sensor (Decagon Devices, WA, USA) with } \\
\text { SMR } 100 \text { data recorder (MadgeTech, NH, USA) }\end{array}$ & $5 \min$ & Apr 2008-Feb 2010 \\
\hline
\end{tabular}

a 4 out of 180 records ( $2 \%$ ) were deleted because the amount of throughfall exceeded the cumulative rainfall (likely due to stem flow), which made it impossible to estimate the contributing area. ${ }^{\mathrm{b}}$ In the Valtorto catchment, streamflow was monitored at the catchment and subcatchment scale. ${ }^{\mathrm{c}}$ Given the short distance between the catchments ( 3 km) and their similar elevation, one BaroDiver was used for both catchments. 
a similar jug, and canopy interception was calculated for each jug based on the measured throughfall and the mean cumulative rainfall for that period. Jugs were installed on 17 November 2008 and emptied on 10 occasions until early February 2009. Because air temperatures were low and jugs were emptied during and/or quickly after major rain events, evaporation loss was considered negligible.

\subsubsection{Streamflow}

Streamflow, also referred to as "flow", was measured using V-notch weirs at the outlet of the catchments, and water levels were recorded at 5-min intervals in a stilling pond upstream of each weir. Two different water level probes were used (Diver and Odyssey type, Table 2). The stagedischarge relationship of each weir was determined from a set of manually measured water levels and streamflow (discharge) volumes. Subsequently, the stage-discharge relationships for each weir and water level probe were determined by fitting the power function $Q=\mathrm{a} H^{b}+\mathrm{c}$ (or $Q=\mathrm{a} H^{b}$ in case the intercept was not significant) to the set of measured $Q-H$ points $^{1}$, where $Q$ is the discharge and $H$ is the water level. Diver and Odyssey logger results were highly correlated ( $r>0.999$ for Valtorto and $r>0.982$ for Espinho), and streamflow was therefore calculated as the mean when records of both loggers were available.

The weirs were regularly checked and plant material that could possibly block the flow was removed. In addition, data was deleted when flow was observed to be obstructed - which happened in the Valtorto main weir in early December 2009. In all cases, large data gaps were left as is, while small data gaps $(<2 \mathrm{~h})$ were filled in by linear interpolation.

\subsubsection{Soil moisture}

Soil moisture content was monitored in the Valtorto catchment only, using Madgetech data loggers connected to Decagon EC-5 sensors (Table 2) installed at $2.5 \mathrm{~cm}$ depth. Sensors were installed at 40 sites throughout the catchment, and soil moisture contents were recorded at 5-min intervals.

All soil moisture probes were calibrated in the laboratory before installation in the field, and afterwards validated using soil moisture sampling adjacent to the probes in the field. The laboratory calibration was performed using repacked soil columns with known moisture content, using soil from the Valtorto catchment that was sieved $(2 \mathrm{~mm})$ and repacked at a dry bulk density typical for the catchment $\left(0.88 \mathrm{~g} \mathrm{~cm}^{-3}\right)$. To choose the best calibration curve, different curves (linear or polynomial, fitted to all sensors together or to each sensor individually) were validated with field topsoil moisture contents sampled within $0.5 \mathrm{~m}$ of the probe. Validation sampling

\footnotetext{
${ }^{1} n=49$ and 54 for Valtorto Diver and Odyssey water level recorder (WLR), respectively, $n=17$ for Valtorto subcatchment Diver, and $n=17$ and 16 for Espinho Diver and Odyssey WLR, respectively.
}

was performed on five occasions using soil cores $\left(50 \mathrm{~cm}^{3}\right.$, $0-2.5 \mathrm{~cm}$ deep, $n=209$ for all sampling dates together) that were weighed and oven dried $\left(24 \mathrm{~h}\right.$ at $\left.105^{\circ} \mathrm{C}\right)$ to determine field moisture content.

The final calibration using a 2nd order polynomial (Eq. 1) resulted in an overestimation of $0.034 \pm 0.088 \mathrm{~cm}^{3} \mathrm{~cm}^{-3}$, which may be attributed to probe-to-probe and bulk density variations (Parsons and Bandaranayake, 2009; Rosenbaum et al., 2010), temperature variation (Bogena et al., 2007), small scale variability of soil moisture content in the field (Dekker and Ritsema, 2000), and the presence of rock fragments in the soils in the Valtorto catchment (Table 1).

$\theta=1.59 \cdot 10^{-6} V^{2}+2.15 \cdot 10^{-5} V-0.116$

with $\theta=$ soil moisture content $\left(\mathrm{cm}^{3} \mathrm{~cm}^{-3}\right)$ and $V=$ logger output voltage $(\mathrm{mV})$. The 2 nd order polynomial fitted the lab calibration points $(n=150)$ with an $r^{2}$ of 0.97 .

The present paper discusses the effect of fire on the catchment average soil moisture - spatial differences will be analyzed and discussed in a future paper.

\subsection{Data analyses}

Rainfall, streamflow and soil moisture data was analyzed using R (R Development Core Team, 2010). Since the length of data and the pronounced wet winter seasons made it difficult to distinguish individual storm events, comparisons of treated and untreated catchments before and after the fire were made using hourly, daily and weekly values of rainfall, streamflow and soil moisture rather than on a storm-by-storm basis.

The effects of vegetation cover on canopy throughfall were assessed following a repeated measures experiment, in which the optimal model was selected using a similar approach as described by Webster and Payne (2002) using the nlme package in R (Pinheiro et al., 2009).

Fire-induced hydrological changes were assessed in a number of ways. Initially, pre- and post-fire rainfall-runoff coefficients were compared for the entire monitoring period. To facilitate visual analysis of changed conditions after the fire, daily pre- and post-fire data of rainfall, streamflow and soil moisture were subsequently plotted as quantile-quantile (QQ) graphs (Becker et al., 1988). In these graphs, the quantiles of the pre- and post-fire probability distributions are plotted against each other (rather than the data pairs, which is the case in a scatterplot), and changed conditions post-fire are indicated by deviation of the $\mathrm{y}=\mathrm{x}$ line.

To test whether changes in streamflow response could be attributed to fire, we performed a traditional paired catchment analysis (Clausen et al., 1993) using streamflow data of the main Valtorto (treated) and Espinho (control) catchments. To further assess whether changes in streamflow could be attributed to changes in the rainfall-streamflow relationship, we used ANalysis of COVAriance (ANCOVA), testing for 

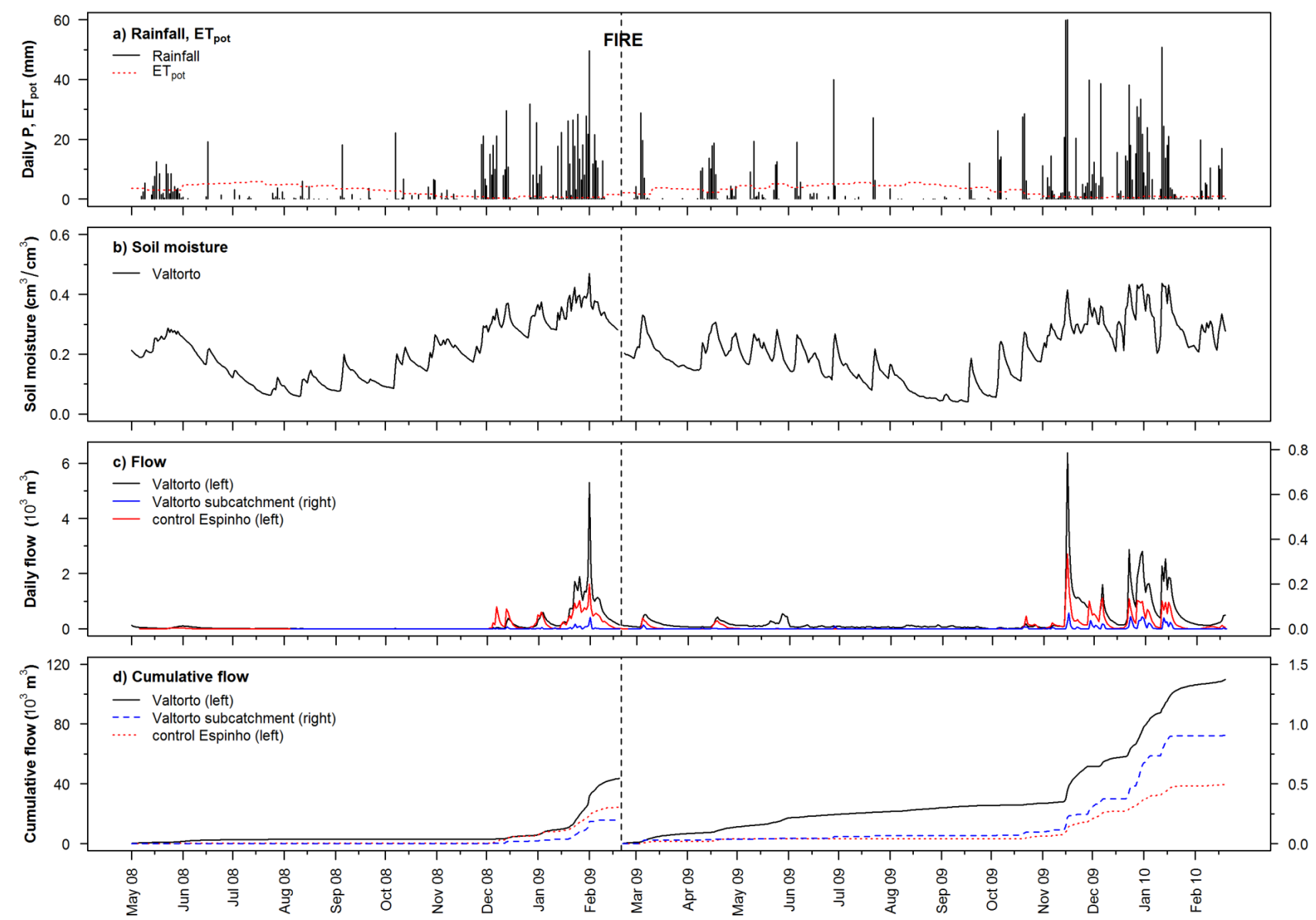

Fig. 2. Time series of (a) daily rainfall $(P)$ and potential evapotranspiration $\left(\mathrm{ET}_{\text {pot }}\right)$, (b) catchment average soil moisture content, (c) streamflow, and (d) cumulative streamflow before and after the experimental fire on 20 February 2009 (vertical dashed line). Note that only the Valtorto catchment was burned; Espinho is the unburned control catchment. Also note that in the streamflow graphs (c, d), the values on the primary y-axis (left) apply to the Valtorto and Espinho main catchments, while the values on the secondary y-axis (right) apply to the Valtorto subcatchment.

the effects of rainfall, fire, and the interaction between rainfall and fire. ANCOVA was also used to test for changes in the rainfall-soil moisture relationship in the treated (Valtorto) catchment. Because we had no soil moisture data in the control catchment, this ANCOVA analysis of the rainfallsoil moisture relationship could not be repeated for the control. Given the effects of scale on the delay between rainfall and streamflow response (i.e. not all rainfall occurring on day 1 flows out on day 1 for a larger catchment) (Skøien et al., 2003) and to reduce the degree of autocorrelation in the data, the ANCOVA analyses were performed using weekly data for the catchment-scale Valtorto and Espinho data, and daily data for the Valtorto subcatchment. Changes in the soil moisture-rainfall relationship were also analyzed using daily data.

To study the timing and the strength of the relationship between streamflow and rainfall in the Valtorto catchment, as well as the relationship between soil moisture and rainfall before and after fire, we performed cross-correlation analy- ses (following Venables and Ripley, 2002) using hourly data. Results of these analyses were compared by extracting the lagtime of the response (time to peak correlation) and the strength of the maximum correlation. For the soil moisture sensors $(n=40)$, these values were then averaged and tested for significant effects of the fire using ANOVA.

Finally, the role of rainfall and soil moisture on streamflow generation was more closely evaluated in the Valtorto subcatchment. Here, the absence of a slow-flow component did allow analysis on a storm-by-storm basis.

\section{Results}

\subsection{Rainfall}

Time series of rainfall, potential evapotranspiration $\left(\mathrm{ET}_{\mathrm{pot}}\right)$, streamflow and soil moisture content are displayed in Fig. 2 and summary statistics are given in Table 3. 
Table 3. Summary statistics of pre- and post-fire rainfall, potential evapotranspiration (ET pot), streamflow (flow) and the catchment average soil moisture, which was calculated by taking the arithmetic mean of the moisture records available for each time step.

\begin{tabular}{|c|c|c|c|c|c|c|c|c|}
\hline \multirow[t]{2}{*}{ Parameter } & & \multicolumn{2}{|c|}{ Rainfall } & \multirow{2}{*}{$\begin{array}{r}\mathrm{ET}_{\text {pot }} \\
\text { (Coimbra) } \\
\% \text { of days }\end{array}$} & \multicolumn{3}{|c|}{ Flow } & \multirow{2}{*}{$\begin{array}{r}\text { Soil moisture } \\
\text { Valtorto } \\
\mathrm{n} / \mathrm{a}\end{array}$} \\
\hline & & $\begin{array}{r}\text { Valtorto } \\
\% \text { of days }\end{array}$ & $\begin{array}{r}\text { Espinho } \\
\% \text { of days }\end{array}$ & & $\begin{array}{r}\text { Valtorto main } \\
\% \text { of days }\end{array}$ & $\begin{array}{r}\text { Valtorto sub } \\
\% \text { of days }\end{array}$ & $\begin{array}{r}\text { Espinho (control) } \\
\% \text { of days }\end{array}$ & \\
\hline \multirow{3}{*}{$\begin{array}{l}\text { Rainfall, } \\
\text { flow occurrence }\end{array}$} & Pre-fire & 45 & 53 & $\mathrm{n} / \mathrm{a}$ & 64 & 18 & 33 & $\mathrm{n} / \mathrm{a}$ \\
\hline & Post-fire & 45 & 51 & $\mathrm{n} / \mathrm{a}$ & 99 & 22 & 48 & $\mathrm{n} / \mathrm{a}$ \\
\hline & & $\mathrm{mm}$ & $\mathrm{mm}$ & $\mathrm{mm}$ & $\mathrm{m}^{3}$ & $\mathrm{~m}^{3}$ & $\mathrm{~m}^{3}$ & $\mathrm{~cm}^{3} \mathrm{~cm}^{-3}$ \\
\hline \multirow{2}{*}{ Sum $^{\mathrm{a}}$} & Pre-fire & 878 & 1069 & 811 & $44 \cdot 10^{3}$ & 195 & $24 \cdot 10^{3}$ & $\mathrm{n} / \mathrm{a}$ \\
\hline & Post-fire & 1352 & 1568 & 1068 & $110 \cdot 10^{3}$ & 904 & $39 \cdot 10^{3}$ & $\mathrm{n} / \mathrm{a}$ \\
\hline \multirow{2}{*}{ Daily mean ${ }^{b}$} & Pre-fire & 3.0 & 3.6 & 2.8 & 148 & 1.0 & 84 & 0.206 \\
\hline & Post-fire & 3.7 & 4.3 & 2.9 & $308 * * * \mathrm{c}$ & $2.5^{*}$ & 108 & 0.204 \\
\hline \multirow{2}{*}{ Daily median } & Pre-fire & 0.0 & 0.2 & 3.1 & 11.8 & 0.0 & 4.5 & 0.199 \\
\hline & Post-fire & 0.0 & 0.2 & 3.4 & 100.3 & 0.0 & 0.0 & 0.203 \\
\hline \multirow{2}{*}{ Daily min } & Pre-fire & 0 & 0 & 0.4 & 0 & 0 & 0 & 0.059 \\
\hline & Post-fire & 0 & 0 & 0.5 & 0 & 0 & 0 & 0.041 \\
\hline \multirow{3}{*}{ Daily max } & Pre-fire & 50 & 43 & 5.9 & $5.3 \cdot 10^{3}$ & 52 & $1.6 \cdot 10^{3}$ & 0.469 \\
\hline & Post-fire & 60 & 65 & 5.6 & $6.4 \cdot 10^{3}$ & 71 & $2.7 \cdot 10^{3}$ & 0.438 \\
\hline & & $\%$ & $\%$ & $\%$ & $\%$ & $\%$ & $\%$ & $\%$ \\
\hline \multirow{2}{*}{$\mathrm{CV}$} & Pre-fire & 228 & 221 & 66.4 & 302 & 452 & 251 & 46 \\
\hline & Post-fire & 236 & 234 & 58.7 & 194 & 344 & 248 & 46 \\
\hline
\end{tabular}

a Note that the pre-fire monitoring period for the Valtorto subcatchment (199 d from 5 August 2008 to 20 February 2009) is shorter than the pre-fire monitoring period for all other sites ( 265 d from 1 March 2008 to 20 February 2009). The post-fire monitoring period is in all cases from 21 February 2009 to 20 February 2010 ( 365 d). b Daily mean values include days without rainfall or streamflow. Asterisks indicate where pre- and post-fire means are significantly different at $p<0.05(*)$, and $p<0.001(* * *){ }^{\mathrm{c}}$ Observed, which is 1.6-fold higher than the value predicted $\left(192 \mathrm{~m}^{3}\right)$ from the rate of change in the control catchment.

Pre- and post-fire monitoring periods are both characterized by a moderately wet spring, a fairly dry summer with occasional rain events, and a very wet winter period (Fig. 2a). The rainfall patterns in Valtorto and Espinho were highly correlated $(r=0.99)$, despite the fact that total rainfall was considerably higher in Espinho (Table 3), likely because of its ridge-side location. Because the post-fire monitoring period was $19 \%$ longer than the pre-fire period, total rainfall and $\mathrm{ET}_{\text {pot }}$ were considerably higher for the post-fire period. However, rainfall occurrence (the fraction of days with rainfall) was similar before and after the fire, and daily mean rainfall and $\mathrm{ET}_{\text {pot }}$ were not significantly different. However, the occurrence of large rain events ( $>20 \mathrm{~mm}$ in one day) was higher after the fire than before (Fig. 3a).

\subsection{Canopy throughfall and interception}

Canopy throughfall of the unburned vegetation in Valtorto was measured in the wet winter period before the fire (Fig. 4), and averaged $51.3 \pm 17.8 \%$ of total rainfall, resulting in an estimated canopy interception of $48.7 \pm 17.8 \%$. Post-fire canopy interception of the regenerating vegetation was not measured, but was assumed to be minimal because of the sparseness of the regenerated vegetation cover, that only reached $30 \%$ one year after the fire (Shakesby et al., 2010).

Pre-fire canopy throughfall was not significantly different between the sites in the Valtorto catchment $(p=0.065)$, al- though it was slightly less for the tall vegetation than for the lower vegetation ("dense" and "medium dense", Fig. 4a). Although throughfall was fairly constant in time, it significantly increased during 15 consecutive rain days mid-January 2009 ( $p<0.0001$, Fig. $4 a)$, indicating that the throughfall fraction increased with increasing rainfall. Following Gash and Morton (1978), total rainfall was plotted against total throughfall, and a linear regression line (Eq. $2, r^{2}=0.84$ ) was fitted through the 150 points (Fig. $4 \mathrm{~b}$ ). Both the slope and the intercept were significantly different from zero, with $p=0$ in both cases. The regression line crosses the $y$-axis at $x=19.5 \mathrm{~mm}$, indicating that roughly the first $19.5 \mathrm{~mm}$ of a rain event was intercepted by the canopy. Because of this offset, the throughfall fraction was not a constant, but increased with rainfall, supporting the increased throughfall observed mid-January 2009 (Fig. 4a). Likewise, the fraction of canopy interception decreased with rainfall, emphasizing that the relative canopy storage was smaller for larger rain events.

$\mathrm{TF}=0.742 * P-14.4$

where $\mathrm{TF}=$ throughfall $(\mathrm{mm})$ and $P=$ cumulative rainfall (mm). Note that this equation is only valid for $P \geq 19.5 \mathrm{~mm}$. 

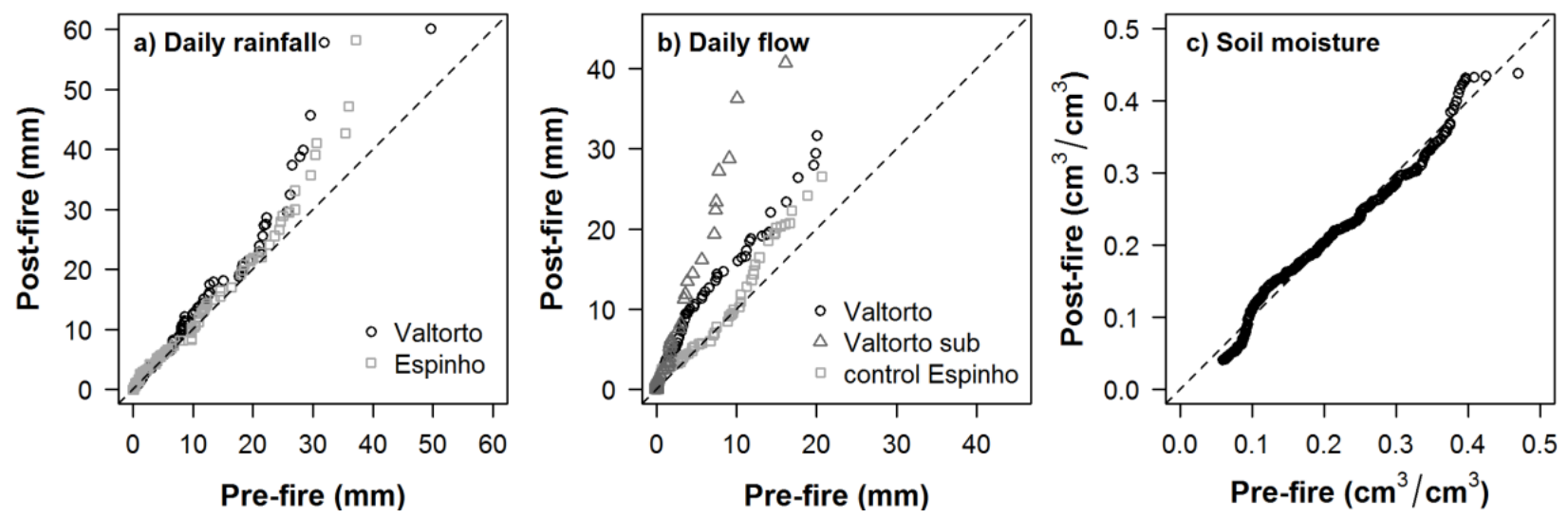

Fig. 3. QQ-plots of (a) daily rainfall, (b) streamflow and (c) soil moisture in the Valtorto (burned) and Espinho (control) catchments, comparing the quantiles of pre- and post-fire distributions relative to the $\mathrm{y}=\mathrm{x}$ line (dashed). Where plotted data deviate from the $\mathrm{y}=\mathrm{x}$ line, pre- and post-fire values are different. The graphs show that post-fire rainfall (a) and flow (b) was higher than pre-fire for all catchments, while the soil moisture distribution (c) remained largely unchanged. To facilitate comparison between the different catchments and scales, flow volumes in graph (b) are given in $\mathrm{mm}$.
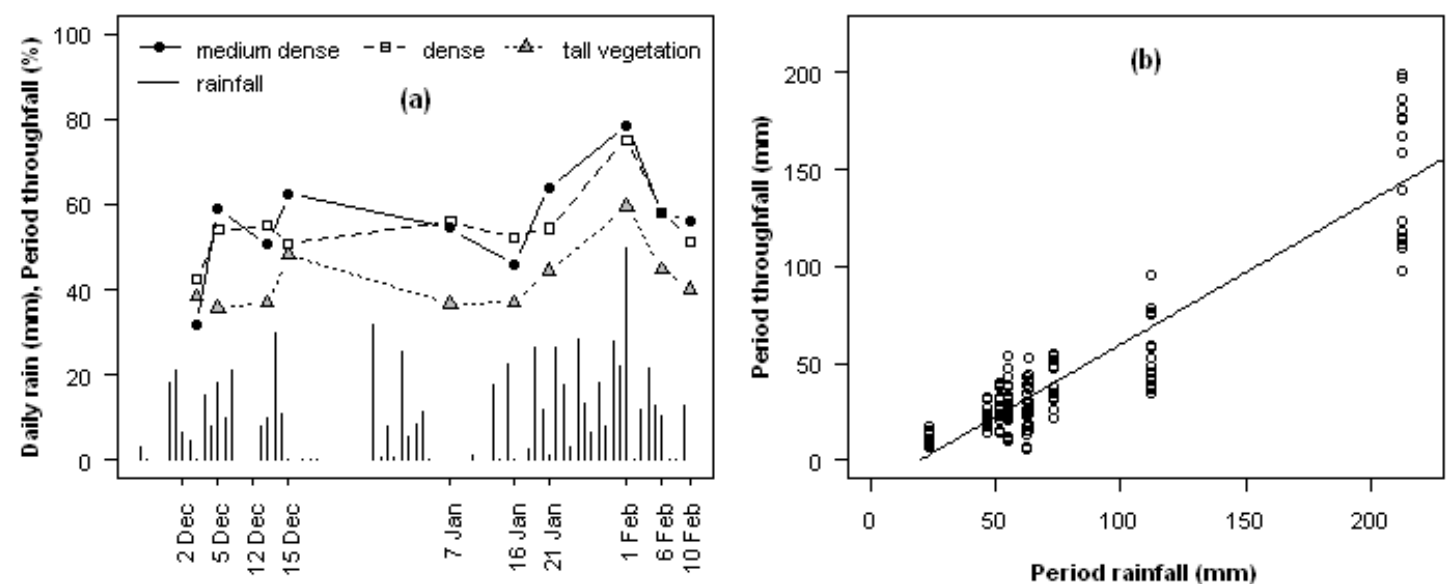

Fig. 4. December 2008 to February 2009 time series of (a) daily rainfall and period total throughfall ratios for different vegetation density and height, and (b) the relation between throughfall amount and total rainfall for each measurement period. Throughfall ratio was defined as the ratio between the amount of throughfall and total rainfall. "Medium dense" vegetation was $\sim 0.4 \mathrm{~m}$ high and had $44 \pm 27 \%$ canopy cover, "dense" vegetation was 0.5 to $0.6 \mathrm{~m}$ high and had $67 \pm 24 \%$ canopy cover, and "tall" vegetation was 1.5 to $2.0 \mathrm{~m}$ high and had $84 \pm 21 \%$ canopy cover.

\subsection{Streamflow}

Similar to the rainfall pattern, streamflow occurred mainly in the winter period, and was highly intermittent at the subcatchment scale. After the fire, the occurrence of streamflow (fraction of days with streamflow $>0$ ) was higher for all three sites (Valtorto and Espinho catchments and Valtorto subcatchment), and resulted in almost year-round streamflow in the main Valtorto catchment after the fire (Table 3, Fig. 2c-d). Because of its larger size, total streamflow in the main Valtorto catchment exceeded that of the control Espinho catchment (Table 3, Fig. 2c-d).
Because of the change in rainfall distribution after the fire (Fig. 3a), changes in streamflow patterns cannot be simply attributed to the effects of fire alone, particularly because streamflow characteristics also changed in the unburned control catchment. However, traditional paired catchment analysis (Fig. 5) showed that the fire significantly increased streamflow volumes in the Valtorto catchment with respect to the unburned control catchment. While the slope of the regression remained unaffected ( $p=0.130)$, the intercept significantly increased $(p=0.002)$, indicating that the fire increased the volume of baseflow. This flow increase corresponds with changes in other measured streamflow parameters. Firstly, mean daily streamflow increased significantly in 


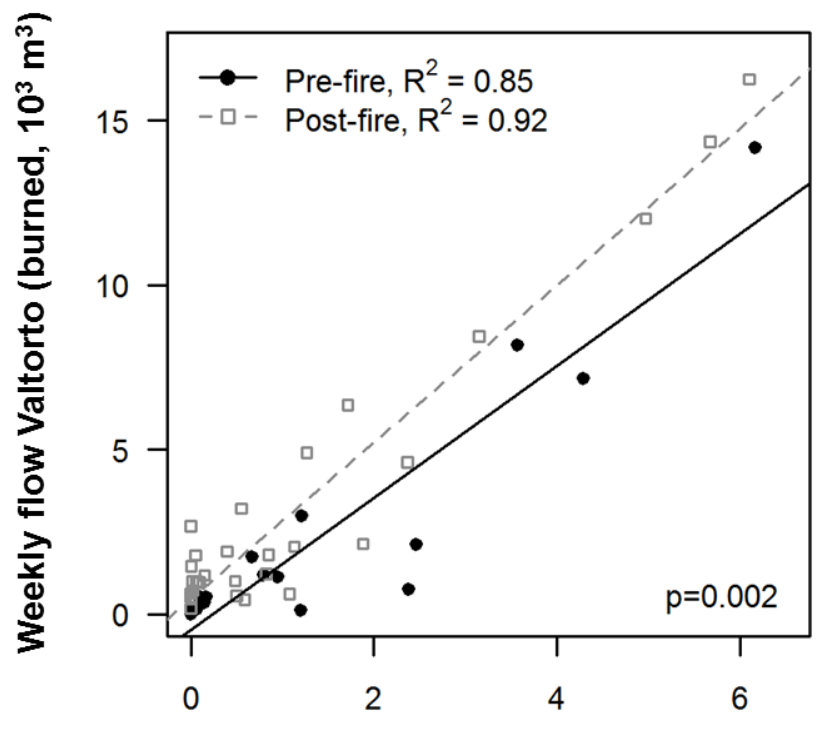

Weekly flow Espinho (control, $10^{3} \mathrm{~m}^{3}$ )

Fig. 5. Paired catchment analysis showing a significant $(p=0.002)$ increase in streamflow in the Valtorto catchment after the fire.

the burned Valtorto catchment, while it did not significantly change in the control Espinho catchment (Table 3). With a mean daily streamflow increase from 148 to $308 \mathrm{~m}^{3}$, post-fire flow in the burned Valtorto catchment was 1.6 times higher than predicted $\left(192 \mathrm{~m}^{3}\right)$ from the rate of change in the control catchment. Secondly, the coefficient of variation for daily streamflow decreased in the burned Valtorto catchment, but remained largely unchanged in the unburned Espinho catchment, suggesting that daily flows in Valtorto had become more continuous and less intermittent (Table 3). Thirdly, the streamflow distribution showed a distinct shift upward from the $y=x$ line in the QQ-plot (Fig. 3b), indicating that streamflow in all catchments was greater post fire than pre fire. However, the upward shift was greater in the burned Valtorto catchment, particularly at the subcatchment scale, than in the unburned Espinho catchment (Fig. 3b). Fourthly, the overall runoff coefficient, the amount of streamflow per unit rainfall across the entire monitoring period, increased considerably more in the burned catchment (1.7 and 2.5-fold increase at the catchment and subcatchment-scale, respectively) than in the control catchment (1.1-fold increase, Fig. 6). And finally, while the lag time between streamflow and rainfall decreased and the lag 0 correlation increased after the fire in both the burned and unburned catchment, the increase in the correlation (and thus the increase in the immediate streamflow response to rainfall events) was most clear in the burned Valtorto catchment, particularly at the sub-catchment scale (Table 4).

More detailed statistical analysis to separate the effects of fire and rainfall variability using ANCOVA revealed no significant interactions between rainfall and fire in any of

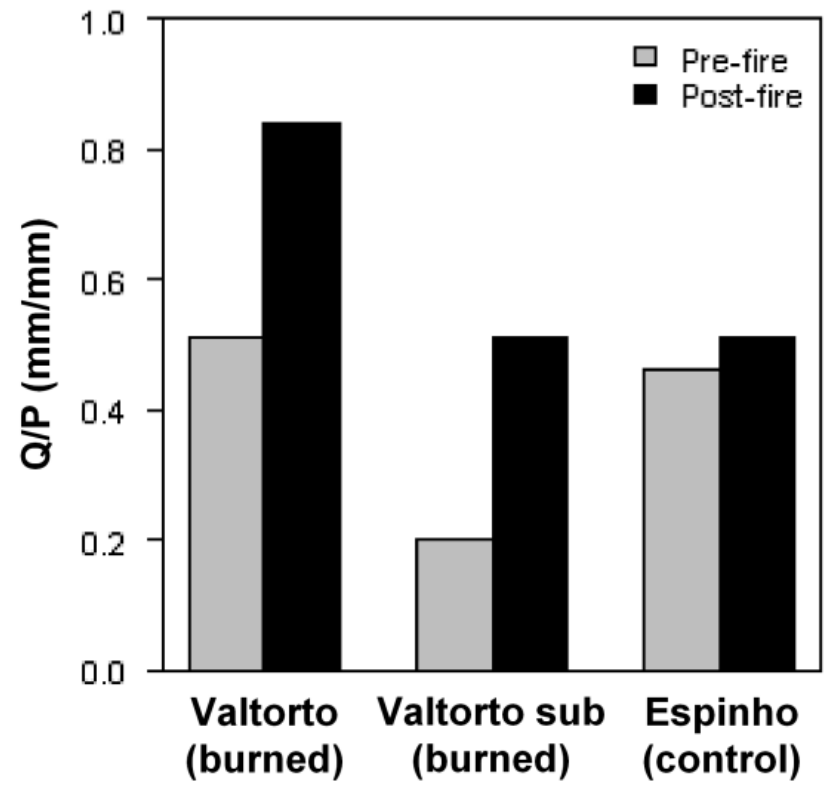

Fig. 6. Runoff coefficient $(Q / P)$ in the Valtorto catchment, the Valtorto subcatchment (sub) and the Espinho catchment, calculated as the total streamflow divided by the total rainfall, for the entire pre- and post-fire monitoring periods.

the catchments, and indicated (not surprisingly) that rainfall was the main explanatory variable for streamflow ( $p=$ 0.000 in all catchments). While the slope of the rainfallstreamflow relationship was not affected by fire in any of the catchments ( $p=0.903,0.126$ and 0.605 for the Valtorto, Valtorto sub and control Espinho catchments, respectively), and the intercept remained unchanged in the control catchment $(p=0.955)$, the intercept in the burned catchment did change, resulting in a shifted rainfall-streamflow relationship (Fig. 7). Although this shift was not significant at the catchment scale $(p=0.323)$, it was significant at the subcatchment scale $(p=0.048)$ where the shift in the relationship was also the greatest (Fig. 7).

\subsection{Soil moisture}

Catchment average topsoil moisture fluctuations in the Valtorto catchment were strongly related to rainfall occurrence both before and after the fire (Fig. 2b). Although the average topsoil moisture content appeared to drop considerably directly after the fire (Fig. $2 b$, near dashed line), the daily catchment mean moisture content for the post-fire period was not significantly different from the pre-fire value (Table 3). The quantile distribution of the catchment average soil moisture content was fairly similar before and after fire (Fig. 3c), however there was a slight increase in the occurrence of low $\left(<0.10 \mathrm{~cm}^{3} \mathrm{~cm}^{-3}\right)$ and high moisture contents ( 0.40 to $0.45 \mathrm{~cm}^{3} \mathrm{~cm}^{-3}$ ) after the fire.

Analysis of covariance (ANCOVA) of the catchment average soil moisture content in the Valtorto catchment indicated 
Table 4. Lagtime of the streamflow and moisture response to rainfall and strength of the correlation between streamflow (flow) and rainfall, and soil moisture and rainfall, derived from cross-correlation analysis of hourly rainfall, streamflow and soil moisture data.

\begin{tabular}{llrrrr}
\hline \multirow{2}{*}{ Parameter } & & Rainfall $\sim$ Flow & & $\begin{array}{r}\text { Rainfall } \sim \text { Soil } \\
\text { moisture }\end{array}$ \\
& & Valtorto main & Valtorto sub & Espinho & Valtorto \\
\cline { 3 - 6 } & Pre-fire & 4 & 1 & 3 & $2.7 \pm 1.7$ \\
Time to peak (h) & Post-fire & 2 & 1 & 1 & $2.1 \pm 1.4$ \\
\hline \multirow{3}{*}{ Strength of correlation } & Pre-fire & 0.391 & 0.513 & 0.475 & $0.319 \pm 0.047$ \\
& Post-fire & 0.440 & 0.636 & 0.536 & $0.340 \pm 0.055$ \\
& \% increase & 13 & 24 & 13 & 6 \\
\hline
\end{tabular}

a Cross-correlation analysis performed on all moisture sites separately for which good quality moisture records were available $(n=39)$, and changes in lagtime $(p=0.058)$ and correlation strength $(p=0.080)$ were analyzed using ANOVA.

a) Valtorto

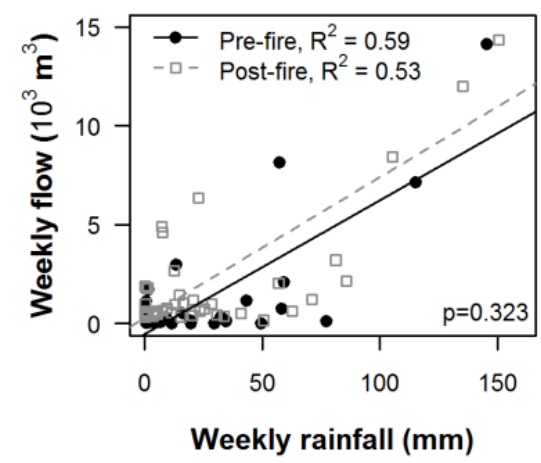

b) Valtorto subcatchment

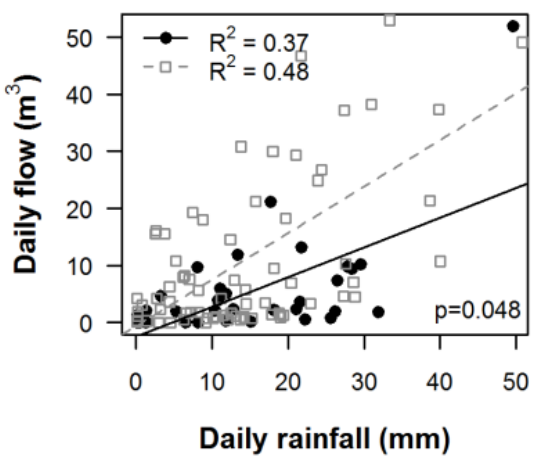

c) Espinho (control)

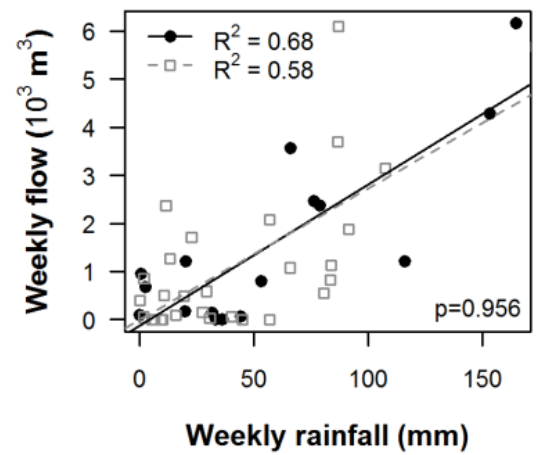

Fig. 7. Rainfall-streamflow relationships in (a) the burned Valtorto catchment (based on weekly data), (b) the Valtorto subcatchment (based on daily data) and (c) the Espinho control catchment (based on weekly data). R2 values refer to the goodness of fit of the regression lines, and $p$-values indicate whether the intercepts of the pre- and post-fire regression lines were significantly different, and thus indicate whether or not the fire significantly changed the rainfall-streamflow relationship.

that there was a significant interaction $(p=0.0001)$ between rainfall and fire. This indicated that the response of the average soil moisture content to fire varied with rainfall amount, for example, that fire affected the soil moisture content on dry days differently than on rainy days. To illustrate: mean soil moisture content on dry days decreased from $0.171 \mathrm{~cm}^{3} \mathrm{~cm}^{-3}$ before the fire to $0.157 \mathrm{~cm}^{3} \mathrm{~cm}^{-3}$ after $(p=$ 0.061 , while the mean soil moisture content on days with rainfall slightly increased from 0.249 to $0.261 \mathrm{~cm}^{3} \mathrm{~cm}^{-3}$ $(p=0.266)$.

The changed soil moisture response on dry and rainy days was also visible in the cross-correlation analysis between rainfall and soil moisture content (Table 4). After the fire, soil moisture content was more strongly correlated to rainfall at lag 0 than before the fire, which was indicated by an increase in cross-correlation from 0.319 to 0.340 (Table 4) and which suggested a stronger general response of soil moisture to rainfall at $p=0.080$. In addition, a decrease in the lag to the maximum correlation was observed from 2.7 to $2.1 \mathrm{~h}$ $(p=0.058)$, suggesting a more rapid response to rainfall after the fire. However, for greater lag times, the correlation between rainfall and soil moisture decreased after the fire for all sites, resulting in a catchment average change depicted in Fig. 8. The initial increased response of soil moisture to rainfall was therefore followed by a long period of decreased response, suggesting that the burned soil dried out more quickly after rain events.

\subsection{Effect of rainfall and soil moisture on streamflow generation}

As mentioned previously, rainfall was a significant predictor of streamflow in all catchments (Fig. 7). The role of rainfall and soil moisture on streamflow generation was more closely studied in the Valtorto subcatchment, where the rapid streamflow response and absence of a slow flow component facilitated analysis on a storm-by-storm basis. Closer analysis of the subcatchment's daily rainfall-streamflow relationship indicated that in addition to an increase in streamflow per unit rainfall (Fig. 6, 7b), the fire also decreased the buffering capacity of the catchment for rainfall, i.e. the amount of rainfall stored in the soil, on the soil surface, and in the 


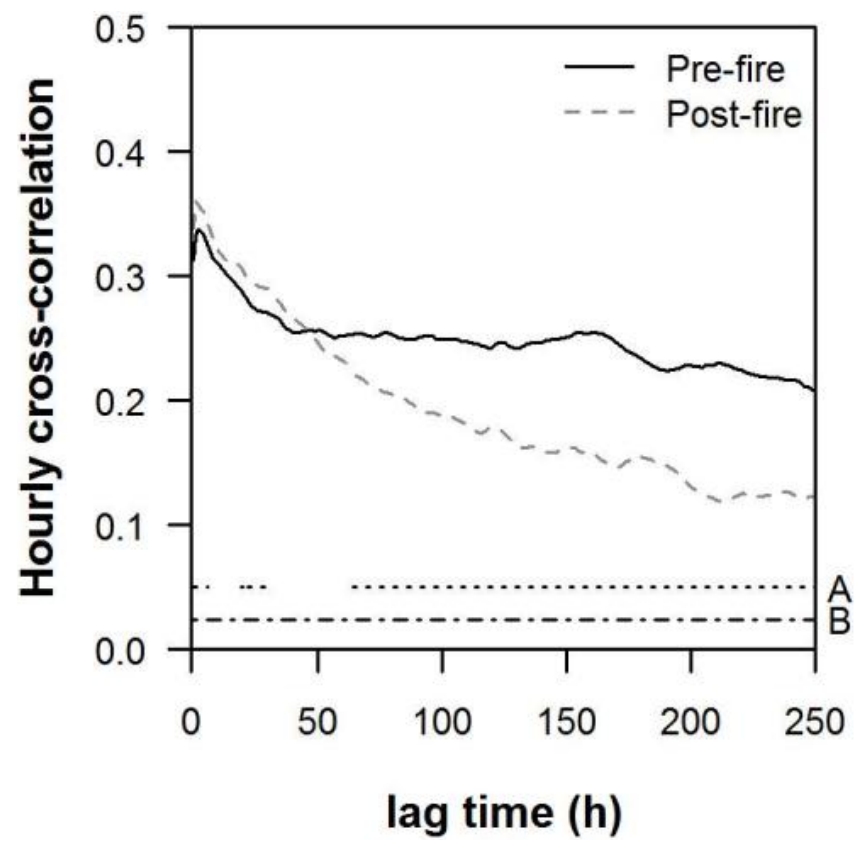

Fig. 8. Cross-correlation between hourly rainfall and catchment average soil moisture content in Valtorto, indicating the timing and the strength of the soil moisture response to the occurrence of rainfall. The dotted horizontal line (A) indicates for which lag times post-fire cross correlation is significantly different $(p<0.05)$ from the pre-fire value, while the dashed horizontal line $(\mathbf{B})$ indicates the confidence interval.

(remaining) vegetation before runoff and streamflow were generated. This resulted in a higher proportion of rainfall events generating streamflow, as shown in Fig. 9a. It furthermore slightly decreased the size of the largest daily rainfall event during which no streamflow was generated, from a pre-fire $22.3 \mathrm{~mm}$ to a post-fire $20.7 \mathrm{~mm}$.

Similarly, the fire significantly decreased the rainfall threshold for runoff generation. While pre-fire $7.2 \pm 6.3 \mathrm{~mm}$ of daily rainfall was buffered without generating streamflow, this reduced to $3.7 \pm 4.5 \mathrm{~mm}$ post-fire ( $p=0.005$, Fig. $9 \mathrm{~b})$. Since streamflow on days with minor amounts of rainfall $(<0.5 \mathrm{~mm})$ usually resulted from heavy rainfall the day before, this analysis was limited to rainfall events $\geq 0.5 \mathrm{~mm}$.

Antecedent soil moisture condition is an important factor determining the rainfall runoff response of a catchment (Benavides-Solorio and MacDonald, 2001; Castillo et al., 2003). The data of the catchment moisture probes suggest that the moisture runoff relationship may have changed. Figure 10 shows the relationship between soil moisture content and the daily streamflow of the Valtorto subcatchment for the two moisture monitoring sites closest to the subcatchment. It is important to note that the rainfall intensity of the events displayed in Fig. 10 did not change significantly after the fire $(p=0.944)$. Figure 10 indicates that streamflow was generated from drier topsoils after the fire than before the fire. Two shifts can be observed: (1) fire decreased the threshold moisture content at which streamflow could be generated (see A, Fig. 10a, b), and (2) fire decreased the threshold topsoil moisture content at which streamflow was always generated (see B, Fig. 10a, b).

\section{Discussion}

\subsection{Fire effects on streamflow generation}

This study focused on the short term catchment hydrological responses as a result of fire. Since rainfall distribution and amount have pronounced effects on streamflow patterns (Beven, 2001; Hewlett and Bosch, 1984), attributing observed hydrological changes to the effects of fire must be treated with caution. Since the changes in rainfall distribution and total rainfall amount (Fig. 3a, Table 3) also affected streamflow in the control catchment (Fig. 3b, Tables 3,4 ), it is reasonable to assume that at least part of the observed changes in streamflow in the burned catchment should be attributed to the change in rainfall. However, traditional paired catchment analysis showed that the fire significantly increased streamflow in the Valtorto catchment (Fig. 5). Moreover, the streamflow distribution (Fig. 3b) and runoff coefficient (Fig. 6) changed more in the burned catchment than in the unburned control, clearly suggesting that fire did have a role in changing streamflow response in the burned catchment. Finally, separation of rainfall and fire effects using ANCOVA (Fig. 7) showed that fire changed the rainfallstreamflow relationship causing an increase in streamflow in the Valtorto subcatchment and possibly in the whole catchment. To explain the observed responses and the difference in response between the catchment and the subcatchment scale we present a diagram that summarizes the changes in the short term hydrological balance due to fire (Fig. 11).

Increases in streamflow after fire have also been observed by others (Lavabre et al., 1993; Scott, 1993, 1997; Seibert et al., 2010), and are often attributed to decreased canopy interception storage (e.g. Scott and Van Wyk, 1990). Canopy interception in the winter before the fire averaged $48.7 \%$ of total rainfall (Fig. 4a). This value is fairly high compared to the few data available on shrub interception (Dunkerley, 2000), but can likely be attributed to the dense canopy cover (Table 1) and the rapid drying of the upper canopy between rain events. Because of the high interception storage, removal of vegetation by fire nearly doubled the effective rainfall (Fig. 11).

Additional data suggests that there are more contributing factors apart from reduced canopy interception. For instance, reduced interception does not explain the two shifts in the relation between subcatchment soil moisture content and rainfall (Fig. 10), i.e. the shift towards streamflow generation on drier soil ("A") and the shift towards decreased rainfall buffering after the fire ("B"). Since the fire did not 
a) Rain generating flow

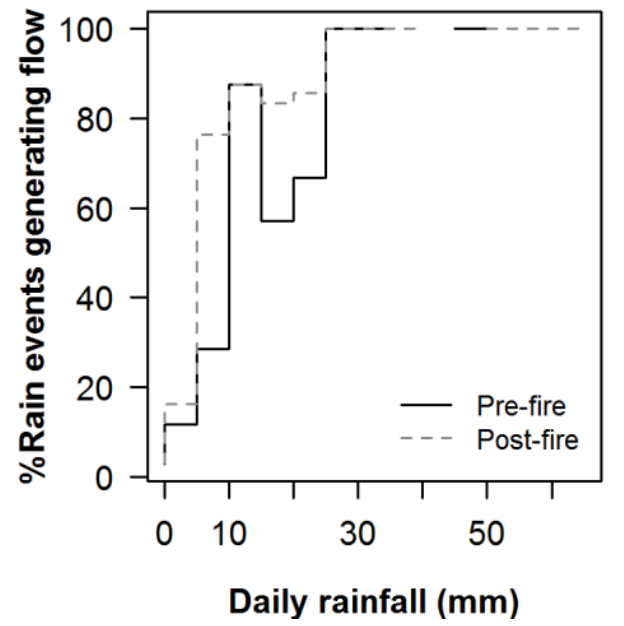

b) Rain not generating flow

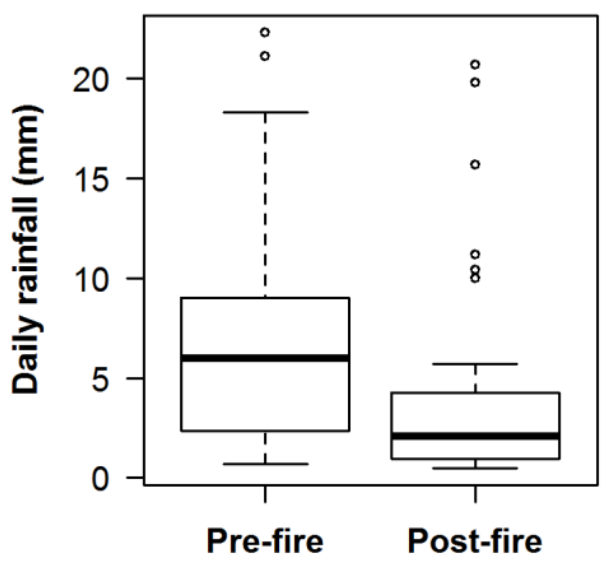

Fig. 9. (a) Proportion of daily rainfall events $>0.5 \mathrm{~mm}$ generating streamflow and (b) size of daily rainfall events $>0.5 \mathrm{~mm}$ not generating streamflow in the Valtorto subcatchment before and after the fire.

a) Site a

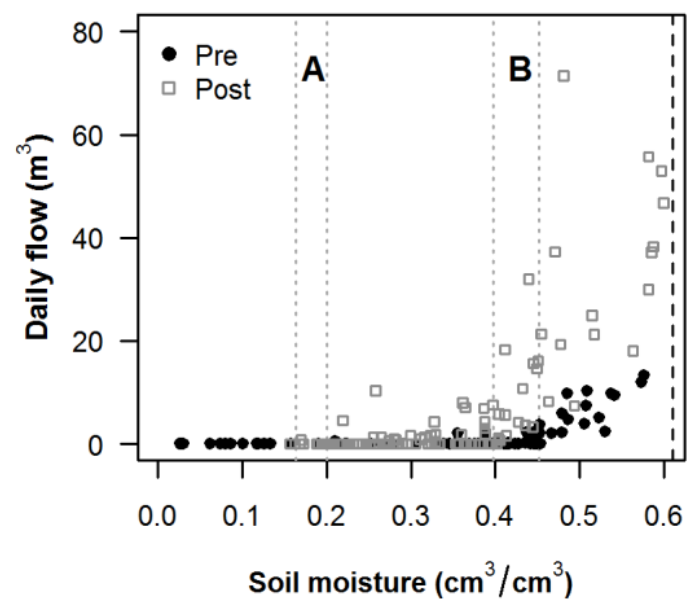

b) Site b

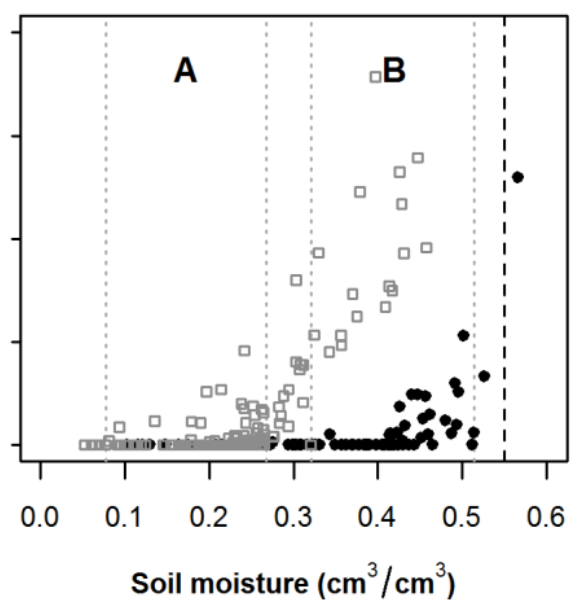

Fig. 10. Daily average soil moisture content and daily streamflow for the Valtorto subcatchment for days that rainfall occurred pre- and post-fire. Moisture records for the two sites closest to the subcatchment (Fig. 1c) are given (with 28 and $17 \%$ missing data periods for site (a) and (b), respectively). Note that pre- and post-fire rainfall intensities of the events displayed were not significantly different, and that the black dashed line indicates total porosity (Stoof, 2011). After the fire, the subcatchment generated streamflow for lower moisture content; shift A indicates the shift in the threshold moisture content at which streamflow could be generated, while shift B indicates the shift in the threshold moisture content at which streamflow was always generated.

change soil bulk density, porosity or hydraulic conductivity (Stoof, 2011), the observed shifts cannot be attributed to a change in these soil properties. Nor can they be explained by changes in rainfall intensity, because the intensity of the rain events generating streamflow in the subcatchment did not change significantly. They could be attributed to surface sealing (Larsen et al., 2009), which was not assessed in the catchment but neither observed during any of the field visits. However, we suggest that the shift towards streamflow generation on drier soil may be attributed to soil wa- ter repellency, and that the shift towards decreased rainfall buffering may be explained by the combined effects of soil water repellency (discussed below) and the decrease in surface roughness that was observed after the fire (Stoof, 2011). Surface roughness or microtopography is generally caused by plant litter or surface rock fragments, and has a small but important role in surface water storage (Govers et al., 2000). Because it increases the amount of water ponding on the soil surface (Fig. 11), surface roughness can delay the initiation and amount of overland flow. Consequently, the decrease 
in surface roughness may have been an additional contributing factor to the more rapid generation of overland flow and reduction in rainfall buffering shown in Figs. 9a and 10.

\subsection{Role of soil moisture and implications for soil water repellency}

Given the effect of vegetation cover on soil moisture status (Hulbert, 1969; Stoof et al., 2011; Sumrall et al., 1991; White and Currie, 1983), the more rapid drying of the topsoil recorded in this study (Fig. 8) and the decreased topsoil moisture content on dry days are likely explained by post-fire exposure of the soil to atmospheric forcings resulting from vegetation removal. Since topsoil moisture content was not significantly changed by the fire itself (Stoof et al., 2011), post-fire soil exposure may also explain the drop in topsoil moisture content between the fire and the reinstallation of the sensors (Fig. 2b). In addition to protecting the soil from drying, vegetation cover can also prevent the soil from wetting (Stoof et al., 2011). Vegetation removal therefore also seems to have caused the stronger and faster initial response of soil moisture to rainfall after fire illustrated in Table 4 and Fig. 8. Both observations suggest changes in the development and elimination of soil water repellency after the fire, as will be discussed in the following paragraphs.

Like many soils worldwide (DeBano, 2000a; Dekker et al., 2005), soils in the Valtorto catchment exhibit water repellency regardless of fire (Stoof et al., 2011). While water repellency was prevalent in the catchment before the fire, there was a significant increase in water repellency directly after the fire, as well as faster development of repellency during dry periods in the burned areas, which was largely attributed to post-fire soil exposure (Stoof et al., 2011). Since soil water repellency in Valtorto was inversely related to soil moisture content (Stoof et al., 2011), the lower soil moisture contents resulting from the rapid drying of the topsoil after rainfall illustrated in Fig. 8 resulted in faster (re)development of soil water repellency and inhibition of infiltration. However, the presence of water repellency inhibits water uptake by soils - thus creating a vicious cycle in dry periods. The resulting impact on streamflow generation is suggested in Fig. 10, with a lower soil moisture threshold for streamflow generation after the fire, as well as a higher fraction of rainfall events generating (overland) flow on dry soil. Since soil properties like porosity and saturated hydraulic conductivity were not significantly affected by the fire (Stoof, 2011), and rainfall intensity of the events displayed in Fig. 10 also remained unchanged, the increased streamflow response to rainfall events occurring on dry soil may be attributed to a more prominent role of soil water repellency in the burned landscape, as suggested by Stoof et al. (2011). After fire, the faster (re)development of soil water repellency therefore contributed to a higher sensitivity to overland flow (Fig. 10) - especially for short duration rainfall events. This may explain the increased soil erosion rates observed in the catchment after the fire (Shakesby et al., 2010).

The impact of the faster development of soil water repellency should not be assessed without considering the effects of its more rapid elimination resulting from the higher effective rainfall after the fire (Stoof et al., 2011). The more rapid elimination of soil water repellency for burned soil observed by Stoof et al. (2011) is consistent with the faster and stronger initial response of soil moisture to rainfall after fire (Table 4, Fig. 8), which suggests that faster disappearance of soil water repellency improves infiltration. As a result, overland flow risk may be reduced during prolonged rainfall events, which, along with the reduced transpiration (Silva et al., 2006) (Fig. 11), could increase (sub)soil water storage. In contrast, the increased topsoil evaporation (Fig. 11) would affect only the top few cm (Wythers et al., 1999). The potential increase in the amount of water stored in the subsoil may explain the increase in dry season flow observed in the present study (Fig. 2c-d, Table 3) as well as in other studies (Berndt, 1971; Hibbert, 1967). Given the fact that (postfire) plant growth is strongly related to soil water availability (García-Fayos et al., 2000; Kasischke et al., 2007; RuizSinoga et al., 2011; Yang et al., 2010; Zald et al., 2008), the possible increase in subsoil water storage may considerably favor plant recovery in burned areas. Since subsoil moisture content was not measured in this study, no definite conclusion can be drawn, however, it is an interesting topic for further study.

\subsection{Synopsis of fire impact on hydrology}

As pointed out, fire-induced changes to the hydrological balance are summarized in Fig. 11, which illustrates the impact of fire on soil moisture and water fluxes. After the fire there is a reduced interception capacity $\left(I_{\text {int }}\right)$ and, consequently, an increase in effective rainfall $\left(P_{\text {eff }}\right)$. A drop in plant transpiration $(T)$ may cause a further increase in (sub)soil water availability and streamflow $\left(Q_{\mathrm{s}}\right)$, while increased soil evaporation $\left(E_{\text {soil }}\right)$ causes more rapid drying of the topsoil. Topsoil water repellency is therefore more rapidly triggered, resulting in an increased risk of overland flow risk for small rain events. The risk of overland flow $\left(Q_{\mathrm{f}}\right)$ is additionally increased through a reduction in surface water storage $\left(S_{\mathrm{s}}\right)$ resulting from reduced surface roughness after the fire. This increase in overland flow risk may however be (partly) counterbalanced by the more rapid elimination of soil water repellency during extended rainfall events, which could enhance subsoil infiltration and water storage and streamflow $\left(Q_{\mathrm{s}}\right)$.

Since vegetation and litter cover will return with time after the fire, the net effect of the processes indicated in Fig. 11 on streamflow will vary with time following fire, and decrease with the reestablishment of the vegetation cover. The net effect will furthermore depend on the type and the age of vegetation, since canopy interception and transpiration vary with 

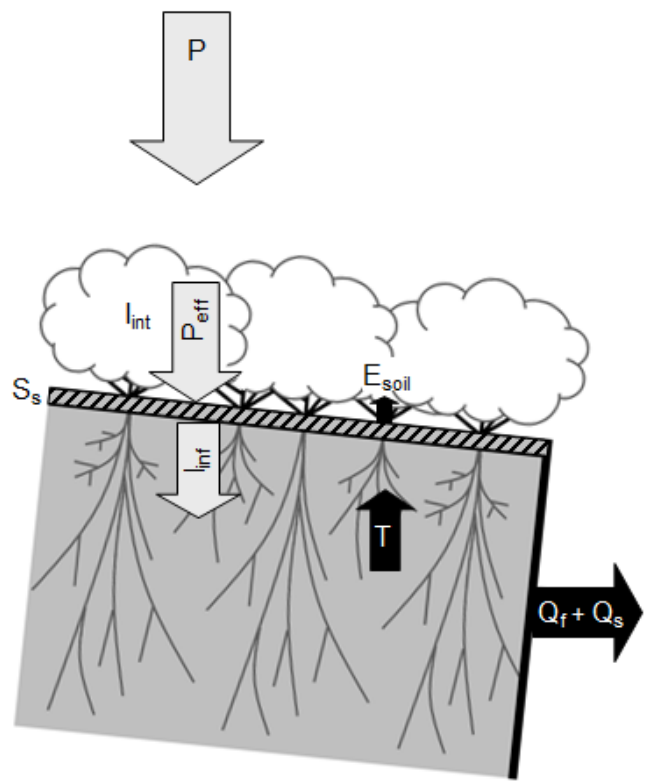

Pre-fire

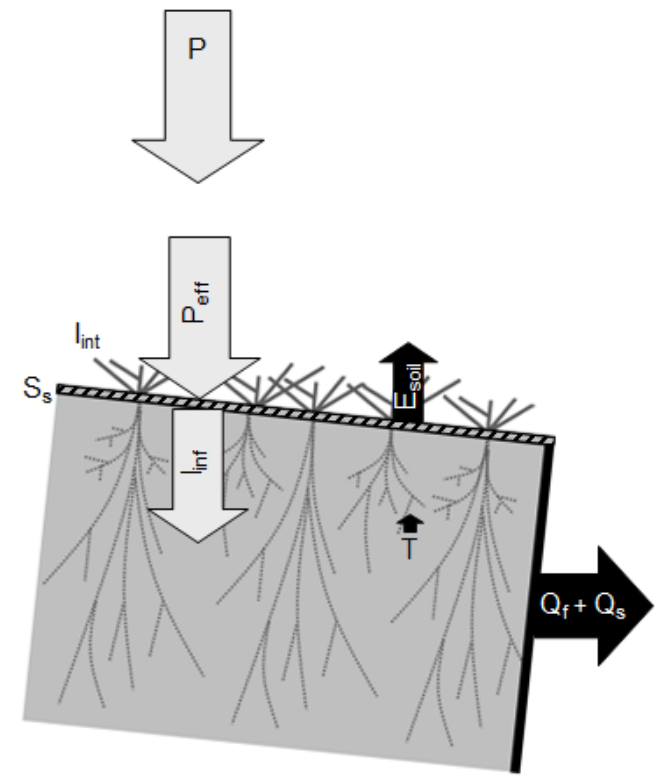

Post-fire

Fig. 11. Fire impact on hydrology, showing pre- and post-fire water fluxes and rainfall partitioning. Grey arrows indicate water gain, black arrows indicate water loss from the soil profile. $P$ is rainfall, $P_{\text {eff }}$ is effective rainfall (the amount of rainfall reaching the ground surface), $I_{\text {inf }}$ is infiltration, $I_{\text {int }}$ is canopy interception, $S_{\mathrm{s}}$ is surface water storage, $E_{\text {soil }}$ is bare soil evaporation, $T$ is plant transpiration, and $Q_{\mathrm{f}}$ and $Q_{\mathrm{s}}$ is the sum of fastflow (surface runoff) and slowflow (subsurface runoff). As the impact of the changes in water fluxes and rainfall partitioning on soil moisture status is highly transient, soil moisture (discussed in Sects. 3.4 and 4.2) is not depicted in this figure.

vegetation type, stand age, and climate (Bosch and Hewlett, 1982; Murakami et al., 2000; Vertessy et al., 2001).

\subsection{Implications for downstream flooding risk and effects of scale}

By increasing streamflow volumes (Fig. 5) and increasing the volume of runoff for a given rain event (Fig. 6), the data support the commonly reported increased flooding risk after fire (Cannon et al., 2008; Conedera et al., 2003; Jordan and Covert, 2009; Rulli and Rosso, 2007). Moreover, by increasing streamflow volumes throughout the year, the fire may also have increased the risk of floods as a cumulative effect. Although it is likely that the observed reduction in canopy storage and surface roughness (Stoof, 2011) also resulted in a stronger and faster response of streamflow after fire, the change in rainfall distribution post-fire (Fig. 3a) prevented assessment of the exact role of the fire. After all, streamflow response was also stronger and faster in the control catchment (Table 4) - likely because of the increased occurrence of large rain events.

Fire impact was highly affected by scale. In all cases, the subcatchment indicated far greater fire impacts than the main catchment: the increase in streamflow distribution (Fig. 3b), runoff coefficient (Fig. 6), and the change in rainfall-streamflow relationship (Fig. 7a-b) were all greater at the small scale than at the catchment scale. Hence, flooding risk inside the catchment itself increased more than the downstream flooding risk.

Reduced response at the larger scale is typical for hydrological processes: moving from the subcatchment scale to the catchment scale, the flow paths lengthen, lag time increases and the opportunities for infiltration and storage due to soil heterogeneity increase (Skøien et al., 2003). However, this also means that the effects of fire on local overland flow generation and subcatchment runoff (as depicted in Fig. 11) get diluted due to these catchment filtering processes, resulting in a less pronounced response at the larger scale (Fig. 7).

This scale effect is often observed in post-fire hydrology: plot-scale runoff coefficients tend to be higher than hillslope- or catchment scale runoff coefficients (Shakesby et al., 2006; Shakesby, 2011), which is generally attributed to increased soil and surface heterogeneity or patchiness at larger scales leading to decreased hydrological connectivity (Doerr et al., 2003; Ferreira et al., 2005, 2008), which may be partly explained by increased spatial variation in burn severity at the larger scale. While post-fire hydrological changes thus decrease when moving up in scale, it is important to note that they may be larger than reported in the present paper in systems where the loss in canopy interception and plant transpiration are greater. This can for instance be the case in forests (Bosch and Hewlett, 1982), or in hotter 
(wild)fires where soil physical changes are more pronounced (García-Corona et al., 2004; Stoof et al., 2010).

\subsection{Lessons for study of fire impact on hydrology}

The markedly different response of the catchment- and subcatchment-scale emphasizes the need to study hydrology at the appropriate scale of interest. Although small plot or hillslope scale studies do provide valuable insight into the processes governing hydrological changes, as demonstrated in Sect. 3.5, they may considerably overestimate the degree of change occurring at the catchment scale as well as miss the increase in dry season streamflow.

The present study shows that it is possible to study fire impact on catchment-scale hydrological processes in a controlled experimental setup. Since studies of wildfire impact on hydrology are hard to plan in advance, this provides a method to purposely study fire effects at the catchment scale. The paired-catchment approach used in the present study and using pre- and post-fire data enabled separation of fire, rainfall variability and site effects through traditional paired catchment as well as ANCOVA analysis. This is particularly interesting in regions where regular catchment scale hydrological monitoring is not common, and where prefire streamflow records are therefore often absent for burned catchments.

Soil, fuel and weather conditions during experimental fires are highly unlikely to match summer wildfire conditions because of safety concerns, which implies that soil and vegetation burn severity of experimental fires will generally be lower than can be expected for wildfires (Cerdà and Robichaud, 2009). This was also demonstrated in the Valtorto fire: despite its high intensity, soil temperature remained surprisingly low and soil physical properties remained unaffected (Stoof, 2011). Experimental fire studies can therefore be used to study catchment-scale effects of prescribed fires or low-severity wildfires that occur when soils and vegetation are still fairly moist. Assessment of catchment-scale effects of summer wildfires remains a matter of "luck". In all cases, finances and logistics will always limit the number of replicates available in catchment-scale studies. To get a full overview of the general effects of fire on hydrology at the catchment scale, a meta-analysis could be done on all the previous studies worldwide, similar to meta-analyses done to assess the effects of deforestation (Bosch and Hewlett, 1982; Brown et al., 2005).

\section{Conclusions}

In a planned catchment-scale fire experiment, this research used pre and post-fire experimental data of paired small catchments to assess the hydrological impact of fire. The changed rainfall conditions following the fire highlighted the value of the adopted sampling design, which allowed assess- ment of fire impact under changed rainfall conditions (because of the availability of pre- and post-fire data) without being hampered by effects of site variability (because of the use of paired catchments). The experiment showed that:

1. Vegetation removal markedly increased the amount of effective rainfall, particularly for smaller rain events. The shrub canopy intercepted on average the first $19.5 \mathrm{~mm}$ of a rain event before the fire, and canopy interception was on average $48.7 \%$ of total rainfall. Since the fire removed nearly all the vegetation from the catchment and canopy cover was only $30 \%$ one year after the fire, post-fire canopy interception was minimal.

2. Fire increased streamflow volumes at the catchment scale. It also increased the runoff coefficient and changed the rainfall-streamflow relationship, particularly at the subcatchment scale.

3. By significantly increasing the amount of streamflow per unit rainfall at the subcatchment-scale, the fire may have increased the risk of flooding inside the catchment. However, as the increase in streamflow was not significant at the catchment scale, fire may have only slightly affected downstream flooding risk.

4. After the fire, the streamflow response to rainfall events was quicker. However, since the control catchment showed a similar change due to a changed rainfall distribution, the degree to which fire played a role in this could not be assessed.

5. After the fire, the moisture content of the $0-2.5 \mathrm{~cm}$ soil layer responded more quickly to rainfall than before, and at the same time this layer dried out more quickly after rain events.

Results support existing knowledge that fire impact on hydrology is largely affected by scale, and emphasize the risk of overestimating hydrological fire impact when upscaling plot- or hillslope scale studies to the catchment scale. This highlights the importance of using the appropriate scale for research design or data use in assessing fire effects.

Finally, results suggest that fire-induced hydrological changes can occur even when soil temperatures during fire remain low. As previous work indicated that soil heating was limited in most of the catchment and soil physical properties remained unchanged, vegetation removal is likely the most significant cause of the observed hydrological changes because of its effects on effective rainfall, soil water repellency fluctuation and surface roughness.

Acknowledgements. The authors thank Rick Shakesby and Rory Walsh for assistance in constructing the weir in Espinho, and for discussion. Also thanks to Floris van Ogtrop for help with R, Thomas Bishop for help with statistical analysis, Tanya Esteves for processing GPS data, Paul Torfs and Todd Walter for discussion, Jan Wesseling and Judith Risse for MySQL assistance, and Demie 
Moore, editor Gerrit de Rooij and three anonymous reviewers for their useful comments on an earlier version of the manuscript. Valuable assistance in the field was received from Carla Ferreira, Célia Bento, Annemieke de Kort, Ayolt Mansholt, Erik Slingerland, Jonathan van den Berg, Oscar González-Perez, Edivaldo López-Thomas, Simon Drooger, and Wouter Mol. This study was partly funded by an International Association of Wildland Fire (IAWF) Scholarship, and by the DESIRE project (Contract 037046, 2007-2011), a European Commission project in the VI Framework Program "Global Change and Ecosystems". The opinions expressed in this paper are those of the authors and do not necessarily reflect the views of the European Commission.

Edited by: G. H. de Rooij

\section{References}

Becker, R. A., Chambers, J. M., and Wilks, A. R.: The new S language, Wadsworth \& Brooks/Cole, 1988.

Beeson, P. C., Martens, S. N., and Breshears, D. D.: Simulating overland flow following wildfire: mapping vulnerability to landscape disturbance, Hydrol. Process., 15, 2917-2930, 2001.

Benavides-Solorio, J. and MacDonald, L. H.: Post-fire runoff and erosion from simulated rainfall on small plots, Colorado Front Range, Hydrol. Process., 15, 2931-2952, 2001.

Berndt, H. W.: Early effects of forest fire on streamflow characteristics, Department of Agriculture, Forest Service, Pacific Northwest Forest and Range Experiment Station, Portland (OR), US, $11,1971$.

Beven, K. J.: Rainfall-runoff modelling: the primer, Wiley, Chichester, UK, 2001.

Blöschl, G. and Sivapalan, M.: Scale issues in hydrological modelling: A review, Hydrol. Process., 9, 251-290, doi:10.1002/hyp.3360090305, 1995.

Bogena, H. R., Huisman, J. A., Oberdörster, C., and Vereecken, H.: Evaluation of a low-cost soil water content sensor for wireless network applications, J. Hydrol., 344, 32-42, 2007.

Bosch, J. M. and Hewlett, J. D.: A review of catchment experiments to determine the effect of vegetation changes on water yield and evapotranspiration, J. Hydrol., 55, 3-23, 1982.

Bracken, L. J. and Croke, J.: The concept of hydrological connectivity and its contribution to understanding runoff-dominated geomorphic systems, Hydrol. Process., 21, 1749-1763, 2007.

Brown, A. E., Zhang, L., McMahon, T. A., Western, A. W., and Vertessy, R. A.: A review of paired catchment studies for determining changes in water yield resulting from alterations in vegetation, J. Hydrol., 310, 28-61, 2005.

Brown, J. A. H.: Hydrologic effects of a bushfire in a catchment in south-eastern New South Wales, J. Hydrol., 15, 77-96, 1972.

Cammeraat, L. H.: A review of two strongly contrasting geomorphological systems within the context of scale, Earth Surf. Proc. Land., 27, 1201-1222, 2002.

Cannon, S. H., Gartner, J. E., Wilson, R. C., Bowers, J. C., and Laber, J. L.: Storm rainfall conditions for floods and debris flows from recently burned areas in southwestern Colorado and southern California, Geomorphology, 96, 250-269, 2008.

Castillo, V. M., Gómez-Plaza, A., and Martínez-Mena, M.: The role of antecedent soil water content in the runoff response of semi- arid catchments: a simulation approach, J. Hydrol., 284, 114130, 2003.

Cerdà, A. and Robichaud, P.: Fire effects on soils and restoration strategies, Science Publishers, 2009.

Clausen, J. C. and Spooner, J.: Paired watershed study design, EPA 841/F-93/009, p. 8, 1993.

Conedera, M., Peter, L., Marxer, P., Forster, F., Rickenmann, D., and Re, L.: Consequences of forest fires on the hydrogeological response of mountain catchments: a case study of the Riale Buffaga, Ticino, Switzerland, Earth Surf. Proc. Land., 28, 117 129, 2003.

DeBano, L. F.: Water repellency in soils: a historical overview, J. Hydrol., 231-232, 4-32, 2000a.

DeBano, L. F.: The role of fire and soil heating on water repellency in wildland environments: a review, J. Hydrol., 231-232, 195206, 2000 b.

Dekker, L. W. and Ritsema, C. J.: Wetting patterns and moisture variability in water repellent Dutch soils, J. Hydrol., 231-232, 148-164, 2000.

Dekker, L. W., Doerr, S. H., Oostindie, K., Ziogas, A. K., and Ritsema, C. J.: Water repellency and critical soil water content in a dune sand, Soil Sci. Soc. Am. J., 65, 1667-1674, 2001.

Dekker, L. W., Oostindie, K., and Ritsema, C. J.: Exponential increase of publications related to soil water repellency, Aus. J. Soil Res., 43, 403-441, 2005.

Doerr, S. H., Ferreira, A. J. D., Walsh, R. P. D., Shakesby, R. A., Leighton-Boyce, G., and Coelho, C. O. A.: Soil water repellency as a potential parameter in rainfall-runoff modelling: experimental evidence at point to catchment scales from Portugal, Hydrol. Process., 17, 363-377, 2003.

Dunkerley, D.: Measuring interception loss and canopy storage in dryland vegetation: a brief review and evaluation of available research strategies, Hydrol. Process., 14, 669-678, 2000.

Ferreira, A. J. D., Coelho, C. O. A., Shakesby, R. A., and Walsh, R. P. D.: Sediment and solute yield in forest ecosystems affected by fire and rip-ploughing techniques, central Portugal: A plot and catchment analysis approach, Phys. Chem. Earth, 22, 309-314, 1997.

Ferreira, A. J. D., Coelho, C. O. A., Boulet, A. K., Leighton-Boyce, G., Keizer, J. J., and Ritsema, C. J.: Influence of burning intensity on water repellency and hydrological processes at forest and shrub sites in Portugal, Aust. J. Soil Res., 43, 327-336, 2005.

Ferreira, A. J. D., Coelho, C. O. A., Ritsema, C. J., Boulet, A. K., and Keizer, J. J.: Soil and water degradation processes in burned areas: Lessons learned from a nested approach, Catena, 74, 273 285, 2008.

Ferreira, A. J. D., Silva, J. S., Coelho, C., Boulet, A.-K., and Keizer, J. J.: The Portuguese experience in managing fire effects, in: Fire effects on soils and restoration strategies, edited by: Cerdà, A. and Robichaud, P. R., Science Publishers (USA), Enfield, NH, USA, 401-424, 2009.

García-Corona, R., Benito, E., De Blas, E., and Varela, M. E.: Effects of heating on some soil physical properties related to its hydrological behaviour in two north-western Spanish soils, Int. J. Wildland Fire, 13, 195-199, 2004.

García-Fayos, P., García-Ventoso, B., and Cerdà, A.: Limitations to Plant Establishment on Eroded Slopes in Southeastern Spain, J. Veg. Sci., 11, 77-86, 2000.

Gash, J. H. C. and Morton, A. J.: An application of the Rutter model 
to the estimation of the interception loss from Thetford Forest, J. Hydrol., 38, 49-58, 1978.

Gottfried, G. J., Neary, D. G., Baker, M. B. Jr., and Ffolliott, P. F.: Impacts of Wildfires on Hydrologic Processes in Forest Ecosystems: Two Case Studies, in: First Interagency Conference on Research in the Watersheds, edited by: Renard, K. G., McElroy, S. A., Gburek, W. J., Canfield, E. H., and Scott, R. L., US Department of Agriculture, Agricultural Research Service, Benson, AZ, USA, 2003.

Govers, G., Takken, I., and Helming, K.: Soil roughness and overland flow, Agronomie, 20, 131-146, 2000.

Hart, S. C., Classen, A. T., and Wright, R. J.: Long-term interval burning alters fine root and mycorrhizal dynamics in a ponderosa pine forest, J. Appl. Ecol., 42, 752-761, 2005.

Hewlett, J. D. and Bosch, J. M.: The dependence of storm flows on rainfall intensity and vegetal cover in South Africa, J. Hydrol., 75, 365-381, 1984.

Hibbert, A. R.: Forest treatment effects on water yield, International Symposium on Forest Hydrology, Oxford, UK, 1967.

Hulbert, L. C.: Fire and litter effects in undisturbed bluestem prairie in Kansas, Ecology, 50, 874-877, 1969.

Johansen, M. P., Hakonson, T. E., and Breshears, D. D.: Post-fire runoff and erosion from rainfall simulation: contrasting forests with shrublands and grasslands, Hydrol. Process., 15, 29532965, 2001.

Jordan, P. and Covert, S. A.: Debris flows and floods following the 2003 wildfires in southern British Columbia, Environ. Eng. Geosci., 15, 217-234, 2009.

Kuczera, G.: Prediction of water yield reductions following a bushfire in ash-mixed species eucalypt forest, J. Hydrol., 94, 215236, 1987

Kasischke, E. S., Bourgeau-Chavez, L. L., and Johnstone, J. F.: Assessing spatial and temporal variations in surface soil moisture in fire-disturbed black spruce forests in Interior Alaska using spaceborne synthetic aperture radar imagery - Implications for postfire tree recruitment, Remote Sens. Environ., 108, 42-58, 2007.

Langford, K. J.: Change in yield of water following a bushfire in a forest of eucalyptus regnans, J. Hydrol., 29, 87-114, 1976.

Larsen, I. J., MacDonald, L. H., Brown, E., Rough, D., Welsh, M. J., Pietraszek, J. H., Libohova, Z., de Dios Benavides-Solorio, J., and Schaffrath, K.: Causes of post-fire runoff and erosion: water repellency, cover, or soil sealing?, Soil Sci. Soc. Am. J., 73, 1393-1407, 2009.

Lavabre, J., Torres, D. S., and Cernesson, F.: Changes in the hydrological response of a small Mediterranean basin a year after a wildfire, J. Hydrol., 142, 279-299, 1993.

Leighton-Boyce, G., Doerr, S. H., Shakesby, R. A., Walsh, R. P. D., Ferreira, A. J. D., Boulet, A., and Coelho, C. O. A.: Temporal dynamics of water repellency and soil moisture in eucalypt plantations, Portugal, Aust. J. Soil Res., 43, 269-280, 2005.

Llovet, J., Josa, R., and Vallejo, V. R.: Thermal shock and rain effects on soil surface characteristics: A laboratory approach, Catena, 74, 227-234, 2008.

Mayor, A. G., Bautista, S., Llovet, J., and Bellot, J.: Post-fire hydrological and erosional responses of a Mediterranean landscape: Seven years of catchment-scale dynamics, Catena, 71, 68-75, 2007.

McMichael, C. E. and Hope, A. S.: Predicting streamflow response to fire-induced landcover change: Implications of parameter un- certainty in the MIKE SHE model, J. Environ. Manage., 84, 245256, 2007.

Meixner, T. and Wohlgemuth, P. M.: Climate variability, fire, vegetation recovery, and watershed hydrology, in: First Interagency Conference on Research in the Watersheds, edited by: Renard, K. G., McElroy, S. A., Gburek, W. J., Canfield, E. H., and Scott, R. L., US Department of Agriculture, Agricultural Research Service., Benson, AZ, USA, 2003.

Moody, J. A. and Martin, D. A.: Initial hydrologic and geomorphic response following a wildfire in the Colorado Front Range, Earth Surf. Proc. Land., 26, 1049-1070, 2001.

Moreira, F., Rego, F. C., and Ferreira, P. G.: Temporal (1958-1995) pattern of change in a cultural landscape of northwestern Portugal: implications for fire occurrence, Landscape Ecol., 16, 557567, 2001.

Murakami, S., Tsuboyama, Y., Shimizu, T., Fujieda, M., and Noguchi, S.: Variation of evapotranspiration with stand age and climate in a small Japanese forested catchment, J. Hydrol., 227, 114-127, 2000.

Nasseri, I.: Frequency of floods from a burned chaparral watershed, Proceedings of the symposium on fire and watershed management, Sacramento (CA), USA, 26-28 Octoeber 1988. Gen. Tech. Rep. PSW-109, 1989.

Onda, Y., Dietrich, W. E., and Booker, F.: Evolution of overland flow after a severe forest fire, Point Reyes, California, Catena, 72, 13-20, 2008.

Parsons, L. R. and Bandaranayake, W. M.: Performance of a new capacitance soil moisture probe in a sandy soil, Soil Sci. Soci. Am. J., 73, 1378-1385, 2009.

Pausas, J. G.: Changes in fire and climate in the eastern Iberian Peninsula (Mediterranean basin), Climatic Change, 63, 337-350, 2004.

Pinheiro, J., Bates, D., DebRoy, S., Sarkar, D., and R Core team: nlme: linear and nonlinear mixed effects models, $\mathrm{R}$ package version 3.1-93, 2009.

Prosser, I. P. and Williams, L.: The effect of wildfire on runoff and erosion in native Eucalyptus forest, Hydrol. Process., 12, 251265, 1998.

R Development Core Team: R: A language and environment for statistical computing (version 2.9). R Foundation for Statistical Computing, Vienna, Austria, ISBN 3-900051-07-0, 2010.

Rosenbaum, U., Huisman, J. A., Weuthen, A., Vereecken, H., and Bogena, H. R.: Sensor-to-sensor variability of the ECHO EC5, TE, and 5TE sensors in dielectric liquids, Vadose Zone J., 9, 181-186, 2010.

Rosso, R., Rulli, M. C., and Bocchiola, D.: Transient catchment hydrology after wildfires in a Mediterranean basin: runoff, sediment and woody debris, Hydrol. Earth Syst. Sci., 11, 125-140, doi:10.5194/hess-11-125-2007, 2007.

Ruiz-Sinoga, J. D., Martínez-Murillo, J. F., Gabarrón-Galeote, M. A., and García-Marín, R.: The effects of soil moisture variability on the vegetation pattern in Mediterranean abandoned fields (Southern Spain), Catena, 85, 1-11, 2011.

Rulli, M. C. and Rosso, R.: Hydrologic response of upland catchments to wildfires, Adv. Water Resour., 30, 2072-2086, 2007.

Rulli, M. C., Bozzi, S., Spada, M., Bocchiola, D., and Rosso, R.: Rainfall simulations on a fire disturbed mediterranean area, J. Hydrol., 327, 323-338, 2006.

Scott, D. F.: The hydrological effects of fire in South African moun- 
tain catchments, J. Hydrol., 150, 409-432, 1993.

Scott, D. F.: The contrasting effects of wildfire and clearfelling on the hydrology of a small catchment, Hydrol. Process., 11, 543$555,1997$.

Scott, D. F. and Van Wyk, D. B.: The effects of wildfire on soil wettability and hydrological behaviour of an afforested catchment, J. Hydrol., 121, 239-256, 1990.

Seibert, J., McDonnell, J. J., and Woodsmith, R. D.: Effects of wildfire on catchment runoff response: a modelling approach to detect changes in snow-dominated forested catchments, Hydrol. Res., 41, 378-390, 2010.

Shakesby, R. A.: Post-wildfire soil erosion in the Mediterranean: Review and future research directions, Earth-Sci. Rev., 105, 71100, 2011.

Shakesby, R. A. and Doerr, S. H.: Wildfire as a hydrological and geomorphological agent, Earth-Science Rev., 74, 269-307, 2006.

Shakesby, R., Ferreira, C., Walsh, R., Urbanek, E., Ferreira, A., and Stoof, C.: Temporal changes in sediment, organic matter and nutrient losses following an experimental fire in AtlanticMediterranean heath, central Portugal, in: VI International Conference on Forest Fire Research, edited by: Viegas, D. X., Coimbra, Portugal, 15-18 November 2010, 2010.

Silva, J. S., Rego, F. C., and Mazzoleni, S.: Soil water dynamics after fire in a Portuguese shrubland, Int. J. Wildland Fire, 15, 99-111, 2006.

Skøien, J. O., Blöschl, G., and Western, A. W.: Characteristic space scales and timescales in hydrology, Water Resour. Res., 39, 1304, doi:10.1029/2002WR001736, 2003.

Stoof, C. R.: Fire effects on soil and hydrology. $\mathrm{PhD}$ thesis, Wageningen University, Wageningen, The Netherlands, p. 182, 2011.

Stoof, C. R., Wesseling, J. G., and Ritsema, C. J.: Effects of fire and ash on soil water retention, Geoderma, 159, 276-285, 2010.

Stoof, C. R., Moore, D., Ritsema, C. J., and Dekker, L. W.: Natural and fire-induced soil water repellency in a Portuguese shrubland, Soil Sci. Soc. Am. J., 75, 2283-2295, 2011.

Sumrall, L., Roundy, B., Cox, J., and Winkel, V.: Influence of canopy removal by burning or clipping on Emergence of Eragrostis lehmanniana seedlings, Int. J. Wildland Fire, 1, 35-40, 1991.
Thwaites, L. A., De Rooij, G. H., Salzman, S., Allinson, G., Stagnitti, F., Carr, R., Versace, V., Struck, S., and March, T.: Nearsurface distributions of soil water and water repellency under three effluent irrigation schemes in a blue gum (Eucalyptus globulus) plantation, Agr. Water Manage., 86, 212-219, 2006.

USDA: Soil Survey Manual, Agricultural Handbook 18, 1993.

van der Velde, Y., Rozemeijer, J. C., de Rooij, G. H., van Geer, F. C., Torfs, P. J. J. F., and de Louw, P. G. B.: Improving catchment discharge predictions by inferring flow route contributions from a nested-scale monitoring and model setup, Hydrol. Earth Syst. Sci., 15, 913-930, doi:10.5194/hess-15-913-2011, 2011.

Venables, W. N. and Ripley, B. D.: Modern applied statistics with S, Springer, 2002.

Vertessy, R. A., Watson, F. G. R., and O'Sullivan, S. K.: Factors determining relations between stand age and catchment water balance in mountain ash forests, Forest Ecol. Manag., 143, 13-26, 2001 .

Webster, R. and Payne, R. W.: Analysing repeated measurements in soil monitoring and experimentation, Eur. J. Soil Sci., 53, 1-13, 2002.

White, R. S. and Currie, P. O.: Prescribed burning in the Northern Great Plains: yield and cover responses of 3 forage species in the mixed grass prairie, J. Range Manage., 36, 179-183, 1983.

Woods, S. W. and Balfour, V. N.: The effect of ash on runoff and erosion after a severe forest wildfire, Montana, USA, Int. J. Wildland Fire, 17, 535-548, 2008.

Wythers, K. R., Lauenroth, W. K., and Paruelo, J. M.: Bare-soil evaporation under semiarid field conditions, Soil Sci. Soc. Am. J., 63, 1341-1349, 1999.

Yang, H. L., Huang, Z. Y., Ye, Y. Z., Zhu, X. W., Dong, M., and Weng, H. B.: Effects of soil moisture profile on seedling establishment in the psammophyte Hedysarum laeve in the semiarid Otindag Sandland, China, J. Arid Environ., 74, 350-354, 2010.

Zald, H. S. J., Gray, A. N., North, M., and Kern, R. A.: Initial tree regeneration responses to fire and thinning treatments in a Sierra Nevada mixed-conifer forest, USA, Forest Ecol. Manag., 256, 168-179, 2008. 